\title{
Practice makes voters?: Effects of student mock elections on turnout
}

Richard Öhrvall and Sven Oskarsson

The self-archived postprint version of this journal article is available at Linköping University Institutional Repository (DiVA):

http:// urn.kb.se/ resolve?urn=urn:nbn:se:liu:diva-161089

N.B.: When citing this work, cite the original publication.

Öhrvall, R., Oskarsson, S., (2020), Practice makes voters?: Effects of student mock elections on turnout, Politics, 40(3), 377-393. https:/ / doi.org/ 10.1177/0263395719875110

Original publication available at:

https:// doi.org/ 10.1177/0263395719875110

Copyright: Political Studies Association

https:// www.psa.ac.uk/ 


\title{
Practice Makes Voters? Effects of Student Mock Elections on Turnout
}

\author{
Richard Öhrvall * $\quad$ Sven Oskarsson ${ }^{\dagger}$
}

September 4, 2019

\begin{abstract}
Student mock elections are carried out in schools around the world in an effort to increase political interest and efficacy among students. There is, however, a lack of research on whether mock elections in schools enhance voter turnout in real elections. In this paper, we examine whether the propensity to vote in Swedish elections is higher among young people who have previously experienced a student mock election. The analysis is based on unique administrative populationwide data on turnout in the Swedish 2010 parliamentary election and the 2009 European Parliament election. Our results show that having experienced a mock election as a student does not increase the likelihood of voting in subsequent real elections. This result holds when we study both short- and long-term effects, and when we divide our sample into different parts depending on their socio-economic status and study each part separately.
\end{abstract}

Keywords: Political inequality, student mock elections, voter turnout, education

\section{${ }^{*}$ Corresponding author}

Centre for Municipal Studies (CKS), Linköping University and Research Institute of Industrial Economics (IFN), richard.ohrvall@liu.se

$\dagger$ Uppsala University and UCLS, sven. oskarsson@statsvet.uu.se 


\section{Introduction}

Political equality is a democratic ideal, but in reality participation is highly unequal (Lijphart, 1997). People who are rich in socio-economic resources participate to a higher degree than those who are poor in that regard (e.g. Wolfinger and Rosenstone, 1980, Verba et al., 1995). This inequality persists over generations; the socio-economically affluent give their children a head start that makes it difficult for others to catch up (Schlozman et al., 2012, 185-98).

Many scholars have seen the education system as an institution that could level the playing field by providing young people with skills that foster turnout (e.g. Rosenstone and Hansen, 1993, 136). There is also ample evidence of a strong relationship between educational attainment and the propensity to vote (Wolfinger and Rosenstone, 1980; Leighley and Nagler, 2014). Recent studies have, however, questioned whether this relationship is causal, and have argued that it might be a proxy for pre-existing characteristics (Persson, 2014; Berinsky and Lenz, 2011). Today the jury is still out on whether education causes political participation (Persson, 2015b). It might also be that the effects are more nuanced than previously perceived. Some recent studies have found that social science education and civic training in schools can compensate for family-background inequalities and generate more equal political engagement and participation (Neundorf et al., 2016; Lindgren et al., 2017).

An increasingly popular and more explicit way for schools to increase political interest, and to prepare students with the necessary skills for voting, is to arrange student mock elections (Borge, 2016). In many countries, schools arrange mock elections at the time of general elections. In this way, young people who have not come of age can get information on party platforms and practise casting a vote under conditions that resemble real elections. Mock elections are organised in different ways in different countries, and they can target students at various ages. In Sweden, mock elections have been arranged at lower- and upper-secondary schools during election years since at least the end of the 1960s. They have become an important part of the government's efforts to increase political interest and efficacy among Swedish youth. Mock elections could also be seen as an opportunity for students to express their political opinions.

There is a small but growing body of research on student mock elections. Evaluations of Danish mock elections have found that they enhance students' internal political efficacy and improve their political knowledge (Hansen et al., 2015; Hansen, 2017). Borge (2017) found that students who vote in Norwegian mock elections are more likely to also express an inten- 
tion to vote in subsequent real elections. Still, this is a stated intention and does not necessarily mean that they will get out and vote in a subsequent general election. As far as we know, no previous study has examined the effects of student mock elections on turnout in real elections. In this study, we attempt to fill this gap. The analysis is based on unique administrative data with information on turnout in the Swedish 2010 parliamentary election for the whole population that was eligible to vote, as well as other individual characteristics of interest. This data, combined with information about which upper-secondary schools have arranged mock elections in 1998-2010, makes it possible to estimate the effects of having experienced a student mock election on turnout. Apart from arranging a mock election, the participating schools were encouraged to arrange political debates and they also received teaching material to use in the classroom. We consider all these activities to be part of the mock election. Unfortunately, we do not have data on the political debates nor on how teachers used the distributed materials, so we cannot disentangle the various parts in our analysis.

When we study students who were enrolled at Swedish upper-secondary schools during election years 1998-2010, we find that those who were enrolled at a school that arranged a mock election had a slightly higher turnout in the 2010 parliamentary election. However, schools that arranged mock elections did not constitute a random sample of all schools; for example, students in these schools had higher grades and a more privileged socio-economic background. When we add control variables to our models to compensate for such differences, there is no longer any statistically significant difference between students depending on whether or not they experienced a mock election. In other words, mock elections do not seem to have any effect on turnout in subsequent real elections. This result holds when we split our sample based on the students' socio-economic background and examine each part separately, and when we focus on short- or long-term effects. It also holds when we use turnout in the Swedish 2009 election to the European Parliament as our outcome variable, an election where the voting rate is drastically lower than in Swedish national parliamentary elections.

\section{Theory and previous findings}

Research on political participation has long emphasised the relationship between socio-economic factors and political participation (e.g. Campbell et al., 1960, Verba and Nie, 1972). The literature has provided plenty of evidence that people rich in resources are more likely to vote than those who are less resourceful. Many studies have found education to be the socio-economic fac- 
tor that best predicts turnout (e.g. Wolfinger and Rosenstone, 1980; Leighley and Nagler, 2014). Schlozman et al. (2012, 185-98) also see educational attainment as a key factor for reproducing political inequality over generations. There are at least two processes by which such reproduction can take place. First, parents who have a higher education are more likely to discuss political issues at home and thereby instil political interest and engagement in their children. Second, well-educated parents are more likely to have children who pursue a higher education and thereby acquire additional resources (see also Verba et al., 1995, 458-9).

The educational system has also been viewed as an institution that could provide young people with civic skills that in turn foster turnout (e.g. Rosenstone and Hansen, 1993, 136). Schools could thereby compensate for different socio-economic backgrounds among students, and contribute to a more equal political participation. Some scholars have, however, questioned whether the relationship between education and turnout is causal, and have argued that educational attainment might be a proxy for pre-existing characteristics (Berinsky and Lenz, 2011; Persson, 2014). Different studies have reached different conclusions, and there is not yet a clear verdict on whether education causes political participation (Persson, 2015b). However, it might be that the search for population-average effects has led to researchers failing to recognise effects in specific subgroups. For example, Lindgren et al. (2017) found that an increase in schooling duration and amount of social science education in Swedish vocational training programmes led to a decreased gap in turnout, by increasing the likelihood to vote among individuals from families of low socio-economic status.

Previous studies have put emphasis on civic education efforts, as means to help adolescents establish their identity as citizens and enhance their political participation (e.g. Dassonneville et al., 2012; Torney-Purta, 2002). In most modern countries, schools are obligated to provide citizenship education (Geboers et al., 2013). This can include various activities and content; Dassonneville et al. (2012) distinguish between formal civic education, an open classroom climate, and active learning strategies. In a review article, Geboers et al. (2013) concluded that an open and democratic classroom climate seems to promote the development of citizenship among secondary school students, and that a formal curriculum with citizenship projects and courses could be an effective type of citizenship education (see also Kahne and Sporte, 2008; Persson, 2015a). It should be noted, however, that a study by Dassonneville et al. (2012) suggests that only longer, intensive forms of engagement lead to higher levels of political participation. This is relevant for student mock elections, which could be seen as civic education initiatives that are very limited in time. Nevertheless, they are an increasingly used by 
schools in an effort to strengthen political interest and prepare students with the necessary skills for voting.

Student mock elections take place in many countries around the world (Borge, 2016; de Groot, 2017). In some countries they are organised nationally, and in others, such as the US, initiatives to carry them out are taken regionally or even within a single school. The country with the longest history of student mock elections is Norway, where students have participated in such elections since after the Second World War (Borge, 2016). In recent decades, the elections have been more formalised and national results have been disseminated. These results are widely covered in the national newspapers and on television, partly because the mock election outcomes have been shown to be predictive of the election results in the national elections. In Norway, all upper-secondary schools arrange mock elections. Apart from casting a vote, the students get to listen to political debates and visit an election square where they can meet and interact with party members from the political youth organizations (Borge, 2016).

Using survey data, Borge (2017) found that Norwegian students who vote in mock elections are also more likely to express an intention to vote in subsequent real elections. However, there is, as acknowledged by Borge, a difference between the intention to vote and actually casting a ballot in an election that takes place later on. Furthermore, students who vote in a mock election are likely to be different from non-voters in various aspects, implying that any correlation between turnout in the mock election and stated interest in voting in a subsequent election might be non-causal. It should also be noted that Borge did not find any relationship between attending the political debate or the election square and the intention to vote in subsequent election.

In Denmark, mock elections for students at lower-secondary school have been carried out nationally since 2015 (Hansen et al. 2015). In some key aspects, they differ somewhat from mock elections in other countries; they are carried out several months ahead of the real elections and therefore also before the political campaigns heat up. Furthermore, the Danish mock elections include different pre-determined activities that the students are supposed to carry out at school over three weeks. Evaluations using control groups and panel data have found that the Danish mock elections enhance students' internal efficacy and improve their political knowledge (Hansen et al. 2015; Hansen, 2017). The evaluations do not, however, examine any effects on voter turnout.

There is less research on mock elections in other countries, but a few results are still worth mentioning. Syvertsen et al. (2009) studied a randomised trial of election-based civics programmes in US high schools, and they found significant effects on students' self-reported ability to cast an informed vote, 
knowledge of the voter registration process, and sense of civic obligation. In a study of Western Illinois University's 2007 Mock Presidential Election, Deitz and Boeckelman (2012) found higher levels of information and competency about the presidential election process and increased levels of political interest and civic engagement among participants compared to non-participants. They also found remaining effects in a follow-up survey one year later.

The question of student mock elections can also be tied to the growing body of research on voting as a habit. Some studies have found that the very act of voting is self-reinforcing (e.g. Plutzer, 2002; Gerber et al., 2003; Dinas, 2012). If voting is a habit, then more focus should be directed towards turnout among young people and the context of the first election they encounter. This has led Franklin (2004, 213) to argue for a lowering of the voting age, so that more young people face their first election when still in school and living with their parents. If student mock elections are carried out in a way that resembles a real election, they might offer an alternative way to help promote long-term turnout by giving young people a good first voting experience. On the other hand, there is a fundamental difference between a mock election and a real election, and other studies have reached the conclusion that habits are formed within specific electoral contexts (Meredith, 2009, Coppock and Green, 2016; Bhatti et al., 2016). It should also be noted that some studies have questioned whether voting is an act of habit at all (Gäbler et al., 2017; Bechtel et al., 2018).

\section{The Swedish setting}

In Sweden, elections to the parliament (the Riksdag) are held in September every four years on the same day as elections to county and municipal councils. The voting age has been lowered several times in the past, most recently from 20 to 19 in 1969 and from 19 to 18 in 1975, but since then it has been kept at 18. This means that young people will face their first parliamentary election when they are between 18 and 22 years of age.

The Swedish electoral system is proportional. Turnout in Swedish parliamentary elections is high compared to most other established democracies (Holmberg and Oscarsson, 2004, Blais, 2007; Solijonov, 2016). In the 2010 national parliamentary election, 84.6 percent of the electorate voted. Among young people entitled to vote for the first time in a parliamentary election, the turnout rate was 80 percent (Öhrvall, 2015). Even if Sweden can be seen as country with high turnout, the Swedish elections to the European parliament (EP) have failed to draw the same numbers of voters to the polls as other types of elections. In the 2009 EP election, only 45.5 percent of the 
electorate turned out to vote. Hence, Sweden provides both high turnout and low turnout elections that we can use in our analyses.

\section{The Swedish school system}

At the age of 16, and after completing nine years of compulsory school, young Swedes are entitled to a three-year upper-secondary education free of charge. They typically graduate from compulsory school in June the year they turn 16 and enrol at upper-secondary school in August the same year, even if there is some variation. Upper-secondary education is optional, but most students enrol directly after leaving lower-secondary education and almost all have done so within a few years. Students can choose between 18 national uppersecondary programmes, which are either vocational or preparatory for higher education. They are normally completed within three years. Students who have not successfully graduated from compulsory school can still enrol at an introductory programme, which are intended to help the student to become eligible for a national programme or to find work. Among those students who left lower-secondary school in 2008 with incomplete degrees, 97 percent enrolled in upper-secondary school within four years (Jorsäter and Snölilja, 2018).

\section{Swedish student mock elections}

Since at least the end of the 1960s, mock elections have been held at Swedish lower- and upper-secondary schools during election years (MUCF, 2015). From 1998 onwards, mock elections have been organised as part of a broader initiative with national campaigns and a presentation of the total vote tally. Until 2006, an increasing number of schools organised mock elections. In 2010, the total number of participating schools was about the same as in 2006 , but there was an increase in the number of upper-secondary schools participating, from 396 to 472 schools.

The mock elections are funded by the Swedish government and carried out by the Swedish Agency for Youth and Civil Society together with the Swedish National Agency for Education and the Swedish Election Authority. It is up to each school to decide whether or not they will participate, and that decision is in the hands of the students. In order for a school to be allowed to participate, a group of people in charge at the school level has to be appointed and that group must include some students, usually the members of the student council. This organising group could also include teachers, but this is not necessary in order to participate. 
If a school decides to participate, they receive guidelines on how to carry out the election and how to invite political parties to present their platforms or participate in debates (Ungdomsstyrelsen, 2011). The schools are encouraged by the organising bodies to invite youth organisations from the political parties and arrange debates between them. They also receive material necessary for the election administration, such as paper ballots, voting booths, etc. The purpose is to arrange elections that are as similar to real elections as possible. Initially, the national initiative was almost exclusively focused on political debates and voting in mock elections, but since 2006 packages containing teaching material to be used in the classroom has also been distributed to the participating schools (Ungdomsstyrelsen, 2007, 2011).

These materials include information about the Swedish political system and how to vote, both in the form of text and video. They also contain instructions on how to carry out two separate role-plays with the students, information about experiential learning as a method, and a brochure on icebreakers that could be used before starting the role-playing. In the first roleplay, the students got to decide upon and play out a democratic procedure, and afterwards discuss how the role-playing relates to democratic processes that actually are in place. In the second, the students got to represent different political parties, debate, vote, and finally decide and compromise on various political issues. It should be noted that the teaching material have only been sent to the schools just before the elections. Hence, the initiative has been very limited in time, which has been criticised by the Swedish National Agency for Education (Ungdomsstyrelsen, 2011).

It is up to the teachers at each school to decide on whether to use the distributed material and if so how. In a follow-up survey after the 2010 mock elections, 80 percent of the teachers said that they received the information material and 71 percent claimed that they had used it in their lectures (Ungdomsstyrelsen, 2011). We do not have any data on what parts of the material they used and how, but the most accessed documents was the one with information on the role-play regarding democratic processes.

The average voter turnout among students at those upper-secondary schools that arranged mock elections was 76 percent in 2006 and 65 percent in 2010. Thus, since not all students who were enrolled at a school that arranged a mock election casted a vote, potential effects mock elections on turnout in real elections might be diluted. Nevertheless, most students do cast a vote and, as mentioned earlier, we consider mock elections to be an initiative that also includes political debates and classroom activities.

Results from these elections have gained some media attention, mainly in the local media. However, since the results are not presented until after the general elections have taken place, they do not get much media coverage 
since the media tend to focus on the outcome of the real elections. The reason for not disseminating the results earlier is that the arranging bodies do not want the outcome to affect the general elections.

There have been a few evaluations of the Swedish mock elections. According to a study carried out after the 2006 election, three out of four students stated that a mock election is a valuable tool for increasing political interest and knowledge about politics and social issues (Ungdomsstyrelsen, 2007). The study also included a comparison with a previous survey in 2005 , which showed that the students' interest in politics had increased after the mock election. It should, however, be noted that almost two years passed between the two surveys, so that an increase might also be due to other factors not controlled for. No previous study has evaluated the effect of Swedish mock elections on students' propensity to vote in real elections.

\section{Data and empirical strategy}

This study is based on unique population-wide administrative data. In a recent effort, the complete electoral rolls for the Swedish 2009 EP and 2010 general elections have been scanned and digitised, resulting in validated information on turnout for almost all the seven million individuals who were eligible to vote in the two elections. The reliability of this digitised turnout data have been shown to be very high (Lindgren et al., 2017, 46-49). Since the electoral rolls also include personal identification numbers, we have been able to match them to various administrative registers maintained at Statistics Sweden. Thereby we have access to various socio-economic and demographic variables, including information about educational background for both students and their parents.

In our analysis, we focus on the subset of individuals who were enrolled at an upper-secondary school in the election years 1998, 2002, 2006, or 2010. For this subset, we have added information about their sex, age, average GPA in 9th grade, and which upper-secondary school and programme they were enrolled in. The GPA scores are standardised for each year to mitigate potential problems with grade inflation over time. We have also added a variable regarding immigration background, which is classified into four categories: the first three refer to people born in Sweden with both, only one, or none of their parents born in Sweden, and the fourth category contains foreign-born persons.

We have used Statistics Sweden's Multi-Generation Registry to link all the students included in our sample to their parents. From the digitised electoral rolls, we have retrieved information on the parents' turnout in the 
Table 1: Summary statistics, students enrolled in election years 1998-2010

\begin{tabular}{|c|c|c|c|c|c|}
\hline & Obs. & Mean & Std. Dev. & Min & Max \\
\hline \multicolumn{6}{|c|}{ a) All students } \\
\hline Turnout 2010 general election & 884,545 & .834 & .372 & 0 & 1 \\
\hline Female & 927,153 & .495 & .500 & 0 & 1 \\
\hline GPA (std.) & 915,512 & .000 & 1.000 & -5.167 & 3.127 \\
\hline Parents voted (general) & 874,723 & .905 & .250 & 0 & 1 \\
\hline Parents voted (EP) & 873,395 & .509 & .449 & 0 & 1 \\
\hline Family SES & 926,764 & -.012 & .791 & -1.944 & 3.786 \\
\hline School: Parents voted (general) & 927,152 & .904 & .032 & 0 & 1 \\
\hline School: Parents voted (EP) & 927,139 & .507 & .094 & 0 & 1 \\
\hline School: Family SES & 927,153 & -.012 & .283 & -1.576 & 1.428 \\
\hline School: GPA (std.) & 925,151 & -.001 & .439 & -5.167 & 1.504 \\
\hline
\end{tabular}

b) Students at schools with mock elections

Turnout 2010 general election

Female

GPA (std.)

Parents voted (general)

Parents voted (EP)

Family SES

School: Parents voted (general)

School: Parents voted (EP)

School: Family SES

School: GPA (std.)

\section{$\begin{array}{lll}441,328 & .831 \quad .375\end{array}$}

$\begin{array}{lll}458,221 \quad .048 \quad .990 \\ 437,372 & .905 & .250\end{array}$

$437,372 \quad .905 \quad .250$

$435,798 \quad .508 \quad .449$

$463,721 \quad .045 \quad .803$

$463,909 \quad .904 \quad .032$

$\begin{array}{lll}463,909 & .510 \quad .093\end{array}$

$\begin{array}{lll}463,909 & .017 \quad .283\end{array}$

$463,909 \quad .041 \quad .402$
$463,909 \quad .501 \quad .500$

$\begin{array}{cc}0 & 1 \\ 0 & 1 \\ -5.167 & 2.721 \\ 0 & 1 \\ 0 & 1 \\ -1.933 & 3.786 \\ .5 & 1 \\ .226 & .806 \\ -.930 & 1.036 \\ -3.428 & 1.504\end{array}$

c) Students at schools without mock elections

Turnout 2010 general election

Female

$443,217 \quad .837$

$463,244 \quad .489$

.370

GPA (std.)

Parents voted (general)

$\begin{array}{lll}457,291 & -.048 & 1.008\end{array}$

$\begin{array}{lll}437,351 & .905 & .251\end{array}$

$437,597 \quad .510 \quad .450$

$463,043 \quad-.070 \quad .775$

Family SES

$463,243 \quad .904$

$463,240 \quad .504$

.033

School: Parents voted (general)

School: Parents voted (EP)

$463,244 \quad-.041$

.096

$\begin{array}{ll}0 & 1 \\ 0 & 1\end{array}$

$-5.167 \quad 3.127$

$0 \quad 1$

$\begin{array}{ll}0 & 1\end{array}$

$-1.933 \quad 3.615$

$0 \quad 1$

$0 \quad 1$

$-1.576 \quad 1.428$

\begin{tabular}{lrrrrr} 
School: GPA (std.) & 463,242 & -.042 & .468 & -5.167 & 1.504 \\
\hline \hline & Notes: The data consists of students enrolled at upper-secondary schools in 1998,
\end{tabular}

\begin{tabular}{lllllr} 
School: GPA (std.) & 463,242 & -.042 & .468 & -5.167 & 1.504 \\
\hline \hline
\end{tabular} 2002, 2006, and 2010. Variables with 'School' prefix refer to school averages. GPA refers to average grade in class 9, standardised for each year. Variables regarding turnout refer to voting in the 2010 parliamentary election (general) and the 2009 European Parliament election (EP). Family SES is an average of parental earnings, parental education, and parental occupational status, where all items initially have been standardised to have a mean of 0 and a standard deviation of 1 .

2009 EP and the 2010 general elections and added this to our data material. We have coded the turnout variable from 0 to 1 , where 0 means that neither 
of the parents voted, .5 that one voted, and 1 that both voted. We also use parental characteristics to create a measurement of the socio-economic status (SES) of the students' families. Our approach follows what has previously been used by Lindgren et al. (2019), who in turn have been inspired by the PISA index of economic, social, and cultural status, developed by the OECD (2010).

This measure of family SES is a simple average of parental earnings, parental education, and parental occupational status. All three items are standardised and assigned the same weight in the index. Consequently, our measure of family SES takes on a value of 0 for an individual from a family with an average score on each of the three items, and a value of 1 for an individual from a family that is situated on average one standard deviation above the mean on all items (for more information on this family SES index, see Lindgren et al. (2019)).

Finally, we have matched information about which schools arranged mock elections in 1998-2010 to the sample. This data is obtained from the Swedish Agency for Youth and Civil Society and contains complete information about all schools that have arranged mock elections at the time of the parliamentary elections in 1998-2010. In total, this gives us information about around 900,000 individuals to use in our analyses.

The analyses are carried out using linear regression models..$^{1}$ In our main analyses, the dependent variable is turnout in the 2010 parliamentary election, but we also estimate the same set of models with turnout in the 2009 EP election as the dependent variable. In that way we can study the effect of mock elections on turnout in elections with high as well as low voting rates. Our key independent variable refers to whether or not the students were enrolled at an upper-secondary school that arranged a mock election. In all our models, we have included birth year fixed effects to control for the different ages of the students included in the sample.

It is reasonable to suspect that schools arranging mock elections do not constitute a random sample of all schools. It could be that schools with very engaged teachers or principals are more likely to arrange such elections, and that they also have a positive impact on students' political interest through other means. Students with more advantageous socio-economic background might also be more likely to self-select into schools that are more likely to arrange mock elections. In Table 1, summary statistics for the pooled data that includes all Swedish upper-secondary students, enrolled in election years 1998-2010, are presented. As can be seen from the table,

\footnotetext{
${ }^{1}$ In the Appendix, we show that the results from a logit specification correspond very closely with those presented in the main text.
} 
the differences in parents' turnout among the students who were enrolled at schools with or without mock elections are minuscule, but students in the former group have slightly higher grades and come from slightly more advantageous socio-economic backgrounds. We therefore include both school-level and individual-level control variables in our models. In order to find heterogeneous effects, we also split our sample into quartiles depending on their family SES, and estimate separate models for each quartile.

In the pooled data, the number of students that have been enrolled at a school that arranged a mock election is almost exactly the same as the number of students that have not had this experience. However, as shown in Table 2, the number of students in schools with mock elections has increased over the years. ${ }^{2}$ Still, the differences between the two groups in each year follow the same pattern as in the pooled data (see the Appendix). As mentioned above, we include birth year fixed effects in all our models, which control for differences over time. We have also estimated separated models for students enrolled in specific elections years in 1998-2010. This also provides information about the effect of a mock election on turnout with different lengths of time between the mock election and the real election, which could reveal if there are any short- or long-term effects.

Table 2: Students enrolled at upper-secondary schools, different election years 1998-2010

\begin{tabular}{|c|c|c|c|c|c|c|}
\hline & \multirow{2}{*}{\multicolumn{2}{|c|}{$\begin{array}{c}\text { With } \\
\text { mock elections }\end{array}$}} & \multirow{2}{*}{\multicolumn{2}{|c|}{$\begin{array}{c}\text { Without } \\
\text { mock elections }\end{array}$}} & \multirow{2}{*}{\multicolumn{2}{|c|}{ Total }} \\
\hline & & & & & & \\
\hline & Obs. & In $\%$ & Obs. & In $\%$ & Obs. & In $\%$ \\
\hline 1998 & 39,631 & 8.54 & 201,128 & 43.42 & 240,759 & 25.97 \\
\hline 2002 & 148,196 & 31.95 & 131,398 & 28.36 & 279,594 & 30.16 \\
\hline 2006 & 218,204 & 47.04 & 104,074 & 22.47 & 322,278 & 34.76 \\
\hline 2010 & 57,878 & 12.48 & 26,657 & 5.75 & 84,535 & 9.12 \\
\hline Total & 463,909 & 100 & 463,257 & 100 & 927,166 & 100 \\
\hline
\end{tabular}

\footnotetext{
${ }^{2}$ We have restricted the sample to eligible voters (18 years or older) in the election held on September 19, 2010. Since we only have information on birth month, we have excluded all students enrolled in upper-secondary school in 2010 who were born in September 1992 or later.
} 


\section{Results}

We begin our analysis by estimating the effect of mock elections arranged in connection with the general elections in 1998, 2002, 2006 and 2010 on turnout in the 2010 Swedish parliamentary election. We use pooled data with all students enrolled at upper-secondary schools at the time of all those elections. The results of the estimated models are presented in Table 3 . In the first column, we present a model with only a variable indicating if the student was enrolled at a school with a mock election (and birth year fixed effects, which are included in all models to control for differences in age between students). In this naive model, we find that students who have experienced a mock election are more likely to vote. The estimated effect is small, about .9 percentage points, but statistically significant.

However, as discussed above, schools that arrange mock elections are not a random sample of all upper-secondary schools. Additional control variables are therefore warranted. In the second model, we have added controls for a number of variables measured at the school level: average parental turnout, average family SES and average grade 9 GPA. The estimated coefficients for the control variables mainly have the expected signs; people who are or have been enrolled at schools where their fellow students had a higher GPA in 9th grade or where the parents of the fellow students vote to a higher degree are more likely to vote. However, the average family SES at school level does not have any significant relationship with the likelihood of voting, at least not when all the other variables are included in the model. When we add all these controls in Model 2, the estimated effect of having experienced a mock election diminishes drastically (to .2 percentage points) and is no longer statistically significant.

In our third model, we toss out the control variables in Model 2, and instead add controls for sex, average grade 9 GPA, parental turnout, and family SES - all measured at the individual level. We also add fixed effects for which school programmes the students were enrolled in and immigration background. Once again, the directions of estimated coefficients of the control variables are as expected. The propensity to vote is higher among females, those with higher GPA, and those who have a more advantageous socioeconomic background and parents who voted in the EP and in the general elections. The estimated effect of having been enrolled at a school that arranged a mock election is of about the same magnitude as in Model 2, and not statistically significant. Finally, in the fourth model, we include all the variables used in the previous models. The estimated effect of having attended a school with a mock election is, once again, small in magnitude and not statistically significant. 
As discussed above, in some previous literature the school is seen as an institution that could compensate for differences in socio-economic backgrounds. Thus, the absence of an average effect of mock elections may conceal important heterogeneities. If mock elections were to have such compensatory effects, we would expect a stronger effect of having been exposed to a mock election among those students who are otherwise less likely to vote. On the other hand, it might also be that those with a more affluent socio-economic status are more receptive to the political information provided and more influenced by the experience of casting a mock vote. In search of such heterogeneous effects, we have divided our data into quartiles based on their family SES, and estimated separate models for each quartile. We also added all the previously mentioned control variables to the model. The results are presented in Table 4. The general picture is that there are small differences between the quartiles. The estimated effects of mock elections in all the models are similar in magnitude compared to the corresponding estimates in the pooled data, regardless of family SES, and the estimates are not statistically significant.

In our models, we control for the school context by including variables measured at the school level. Still, it is possible that mock elections have different effects across different school contexts. In order to examine such potential heterogeneity, we have divided our sample into quartiles depending on the average GPA (at grade 9) among students measured at the school level, and estimated separate models for each quartile. We have also done the same exercise but with quartiles based on family SES measured at school level. The results are the same: we find minuscule, non-significant effects of having experienced a mock election on subsequent voter turnout across all sub-groups (see Appendix for details on the estimated models).

Even if we do not find any impact of having attended an upper-secondary school that organised a mock election on turnout in subsequent real elections, there might be short- or long-term effects that get diluted in our pooled data. For this reason, we have estimated separate models for students enrolled in each of the election years 1998-2010. As shown in Table 5, the general pattern is the same in all models, even if the coefficients for some variables vary a bit. More importantly, the estimated effects of mock elections are not statistically significant in any of the models (at the conventional .05 confidence level).

Thus, taken together, we do not find any effect of mock elections on the likelihood of voting in the 2010 national parliamentary elections. It should, however, be noted that turnout rates in these elections are relatively high, even among young people. In order to see if mock elections could have an effect on turnout in elections that draw fewer people to the polls, we have estimated the same models as presented above, but with turnout in the 
Swedish 2009 EP election as the outcome variable. In that election, turnout was only 45.5 percent, scarcely more than half of the turnout in the 2010 parliamentary election. Still, the conclusion is the same-we do not find any effect on turnout due to having experienced a mock election at uppersecondary school - not in the pooled data, or in the data split into quartiles depending on family SES, and nor do we find any short- or long-term effects (see the Appendix). 
Table 3: Turnout in parliamentary election 2010 among students enrolled in election years 1998-2010. OLS regressions

\begin{tabular}{|c|c|c|c|c|}
\hline & 1 & 2 & 3 & 4 \\
\hline Mock election & $\begin{array}{c}0.00931^{\text {*** }} \\
(0.00296)\end{array}$ & $\begin{array}{c}0.00194 \\
(0.00152)\end{array}$ & $\begin{array}{c}0.00205 \\
(0.00151)\end{array}$ & $\begin{array}{c}0.00202 \\
(0.00148)\end{array}$ \\
\hline School: Parents voted (general) & & $\begin{array}{l}0.542^{* * *} \\
(0.0306)\end{array}$ & & $\begin{array}{c}0.0930^{* * *} \\
(0.0313)\end{array}$ \\
\hline School: Parents voted (EP) & & $\begin{array}{l}0.236^{* * *} \\
(0.0175)\end{array}$ & & $\begin{array}{l}0.168^{* * *} \\
(0.0162)\end{array}$ \\
\hline School: Family SES & & $\begin{array}{l}-0.00605 \\
(0.00511)\end{array}$ & & $\begin{array}{l}-0.0107^{* *} \\
(0.00479)\end{array}$ \\
\hline School: GPA (std.) & & $\begin{array}{l}0.0133^{* * *} \\
(0.00295)\end{array}$ & & $\begin{array}{c}-0.0261^{* * *} \\
(0.00273)\end{array}$ \\
\hline Parents voted (general) & & & $\begin{array}{c}0.261^{* * *} \\
(0.00305)\end{array}$ & $\begin{array}{c}0.260^{* * *} \\
(0.00305)\end{array}$ \\
\hline Parents voted (EP) & & & $\begin{array}{l}0.0715^{* * *} \\
(0.00108)\end{array}$ & $\begin{array}{l}0.0695^{* * *} \\
(0.00106)\end{array}$ \\
\hline Female & & & $\begin{array}{l}0.0126^{* * *} \\
(0.00109)\end{array}$ & $\begin{array}{l}0.0122^{* * *} \\
(0.00107)\end{array}$ \\
\hline Family SES & & & $\begin{array}{c}0.00543^{* * *} \\
(0.000674)\end{array}$ & $\begin{array}{c}0.00389^{* * *} \\
(0.000645)\end{array}$ \\
\hline GPA (std.) & & & $\begin{array}{c}0.0304^{* * *} \\
(0.000890)\end{array}$ & $\begin{array}{c}0.0320^{* * *} \\
(0.000778)\end{array}$ \\
\hline Birth year fixed effects & $\checkmark$ & $\checkmark$ & $\checkmark$ & $\checkmark$ \\
\hline School programme fixed effects & & & $\checkmark$ & $\checkmark$ \\
\hline Immigration background fixed effects & & & $\checkmark$ & $\checkmark$ \\
\hline$N$ & 820,083 & 820,083 & 820,083 & 820,083 \\
\hline
\end{tabular}

Notes: Standard errors in parentheses. The models are estimated using pooled data of students enrolled at upper-secondary schools in 1998, 2002, 2006, and 2010. Variables with 'School' prefix refer to averages at school level. Variables regarding turnout refer to voting in the 2010 parliamentary election (general) and the 2009 European Parliament election (EP). Family SES is an average of parental earnings, parental education, and parental occupational status, where all items initially have been standardised to have a mean of 0 and a standard deviation of 1. GPA refers to average grade in class 9, standardised for each year. School programme refers to the 18 national and 5 introductory programmes available at upper-secondary schools. Immigration background is classified into four categories: the first three refer to people born in Sweden with both, only one, or none of their parents born in Sweden, and the fourth category contain foreign-born persons. 
Table 4: Turnout in parliamentary election 2010 among students enrolled in election years 1998-2010, by family SES quartile. OLS regressions

\begin{tabular}{|c|c|c|c|c|}
\hline & Q1 & Q2 & Q3 & Q4 \\
\hline Mock election & $\begin{array}{c}0.00267 \\
(0.00245)\end{array}$ & $\begin{array}{c}0.00145 \\
(0.00223)\end{array}$ & $\begin{array}{c}0.00201 \\
(0.00210)\end{array}$ & $\begin{array}{c}0.00255 \\
(0.00178)\end{array}$ \\
\hline School: Parents voted (general) & $\begin{array}{c}0.121^{* *} \\
(0.0483)\end{array}$ & $\begin{array}{l}0.113^{* *} \\
(0.0509)\end{array}$ & $\begin{array}{c}0.0477 \\
(0.0480)\end{array}$ & $\begin{array}{c}0.0430 \\
(0.0449)\end{array}$ \\
\hline School: Parents voted (EP) & $\begin{array}{l}0.139^{* * *} \\
(0.0253)\end{array}$ & $\begin{array}{l}0.185^{* * *} \\
(0.0246)\end{array}$ & $\begin{array}{l}0.171^{* * *} \\
(0.0214)\end{array}$ & $\begin{array}{l}0.182^{* * *} \\
(0.0231)\end{array}$ \\
\hline School: GPA (std.) & $\begin{array}{c}-0.0330^{* * *} \\
(0.00494)\end{array}$ & $\begin{array}{c}-0.0306^{* * *} \\
(0.00440)\end{array}$ & $\begin{array}{c}-0.0280^{* * *} \\
(0.00303)\end{array}$ & $\begin{array}{c}-0.0151^{* * *} \\
(0.00334)\end{array}$ \\
\hline Female & $\begin{array}{l}0.0218^{* * *} \\
(0.00231)\end{array}$ & $\begin{array}{l}0.0175^{* * *} \\
(0.00215)\end{array}$ & $\begin{array}{c}0.00590^{* * *} \\
(0.00171)\end{array}$ & $\begin{array}{c}0.00631^{* * *} \\
(0.00141)\end{array}$ \\
\hline Parents voted (general) & $\begin{array}{c}0.259^{* * *} \\
(0.00402)\end{array}$ & $\begin{array}{c}0.277^{* * *} \\
(0.00481)\end{array}$ & $\begin{array}{c}0.250^{* * *} \\
(0.00573)\end{array}$ & $\begin{array}{c}0.215^{* * *} \\
(0.00728)\end{array}$ \\
\hline Parents voted (EP) & $\begin{array}{c}0.0739^{* * *} \\
(0.00213)\end{array}$ & $\begin{array}{c}0.0731^{* * *} \\
(0.00193)\end{array}$ & $\begin{array}{l}0.0688^{* * *} \\
(0.00181)\end{array}$ & $\begin{array}{l}0.0626^{* * *} \\
(0.00193)\end{array}$ \\
\hline GPA (std.) & $\begin{array}{c}0.0354^{* * *} \\
(0.00135)\end{array}$ & $\begin{array}{c}0.0373^{* * *} \\
(0.00120)\end{array}$ & $\begin{array}{l}0.0322^{* * *} \\
(0.00114)\end{array}$ & $\begin{array}{c}0.0235^{\text {*** }} \\
(0.00120)\end{array}$ \\
\hline Birth year fixed effect & $\checkmark$ & $\checkmark$ & $\checkmark$ & $\checkmark$ \\
\hline School programme fix & $\checkmark$ & $\checkmark$ & $\checkmark$ & $\checkmark$ \\
\hline Immigration background fixed effects & $\checkmark$ & $\checkmark$ & $\checkmark$ & $\checkmark$ \\
\hline$N$ & 200,341 & 209,760 & 211,092 & 198,890 \\
\hline
\end{tabular}

Notes: Standard errors in parentheses. Students enrolled at upper-secondary schools in election years 1998-2010 have been divided into quartiles depending on their family SES, and a model has been estimated for each quartile. Family SES is an average of parental earnings, parental education, and parental occupational status, where all items initially have been standardised to have a mean of 0 and a standard deviation of 1 . For information about the other variables, see Table 3. 
Table 5: Turnout in parliamentary election 2010 among students enrolled in different election years 1998-2010. OLS regressions

\begin{tabular}{|c|c|c|c|c|}
\hline & 1998 & 2002 & 2006 & 2010 \\
\hline Mock election & $\begin{array}{c}0.000977 \\
(0.00262)\end{array}$ & $\begin{array}{c}-0.0000972 \\
(0.00228)\end{array}$ & $\begin{array}{c}0.00455^{*} \\
(0.00257)\end{array}$ & $\begin{array}{c}0.00296 \\
(0.00337)\end{array}$ \\
\hline School: Parents voted (general) & $\begin{array}{l}0.175^{* * *} \\
(0.0368)\end{array}$ & $\begin{array}{l}0.218^{* * *} \\
(0.0522)\end{array}$ & $\begin{array}{l}-0.0837 \\
(0.0587)\end{array}$ & $\begin{array}{l}-0.0247 \\
(0.0744)\end{array}$ \\
\hline School: Parents voted (EP) & $\begin{array}{l}0.127^{* * *} \\
(0.0183)\end{array}$ & $\begin{array}{l}0.163^{* * *} \\
(0.0259)\end{array}$ & $\begin{array}{l}0.203^{* * *} \\
(0.0271)\end{array}$ & $\begin{array}{l}0.147^{* * *} \\
(0.0320)\end{array}$ \\
\hline School: GPA (std.) & $\begin{array}{c}-0.0220^{* * *} \\
(0.00319)\end{array}$ & $\begin{array}{c}-0.0327^{* * *} \\
(0.00372)\end{array}$ & $\begin{array}{c}-0.0316^{* * *} \\
(0.00428)\end{array}$ & $\begin{array}{c}-0.00800 \\
(0.00539)\end{array}$ \\
\hline Female & $\begin{array}{c}0.00741^{* * *} \\
(0.00162)\end{array}$ & $\begin{array}{l}0.0186^{* * *} \\
(0.00182)\end{array}$ & $\begin{array}{l}0.0123^{* * *} \\
(0.00173)\end{array}$ & $\begin{array}{c}0.00872^{* * *} \\
(0.00255)\end{array}$ \\
\hline Parents voted (general) & $\begin{array}{c}0.191^{* * *} \\
(0.00454)\end{array}$ & $\begin{array}{c}0.226^{* * *} \\
(0.00458)\end{array}$ & $\begin{array}{c}0.299^{* * *} \\
(0.00458)\end{array}$ & $\begin{array}{c}0.407^{* * *} \\
(0.00815)\end{array}$ \\
\hline Parents voted (EP) & $\begin{array}{l}0.0490^{* * *} \\
(0.00176)\end{array}$ & $\begin{array}{l}0.0697^{* * *} \\
(0.00184)\end{array}$ & $\begin{array}{l}0.0905^{* * *} \\
(0.00191)\end{array}$ & $\begin{array}{l}0.0473^{* * *} \\
(0.00254)\end{array}$ \\
\hline GPA (std.) & $\begin{array}{l}0.0247^{* * *} \\
(0.00110)\end{array}$ & $\begin{array}{l}0.0368^{* * *} \\
(0.00124)\end{array}$ & $\begin{array}{l}0.0348^{* * *} \\
(0.00122)\end{array}$ & $\begin{array}{l}0.0232^{* * *} \\
(0.00144)\end{array}$ \\
\hline Birth year fixed effects & $\checkmark$ & $\checkmark$ & $\checkmark$ & $\checkmark$ \\
\hline School programme fixed effects & $\checkmark$ & $\checkmark$ & $\checkmark$ & $\checkmark$ \\
\hline Immigration background fixed effects & $\checkmark$ & $\checkmark$ & $\checkmark$ & $\checkmark$ \\
\hline$N$ & 208,807 & 245,471 & 290,264 & 75,541 \\
\hline
\end{tabular}

Notes: Standard errors in parentheses. A separate model has been estimated for students enrolled at upper-secondary schools in 1998, 2002, 2006, and 2010. For information about the variables, see Table 3 . 


\section{Conclusions}

Student mock elections are carried out in schools in many countries around the world in an effort to increase political interest and efficacy among young people. No previous study has, however, examined whether these mock elections have any effect on the likelihood of voting in real elections. We tackle this question using a unique population-wide dataset on turnout in the Swedish 2010 parliamentary election and the 2009 EP election.

Our results show that students enrolled at an upper-secondary school that arranged a mock election were slightly more likely to vote in a subsequent real election. However, this result is due to differences in student composition between schools that have mock elections and those that do not. When we add variables to control for these differences, the effect of having experienced a mock election on turnout in a general election decreases towards zero and is no longer statistically significant. We also fail to reveal any effects when we split our data according to socio-economic background at the individual or school level. In other words, we find that mock elections do not help to level the playing field by having any compensatory effect on political participation. The conclusion that mock elections do not affect turnout in real elections also holds when we study short- and long-term effects, and we use turnout in the Swedish 2009 EP election as our outcome variable, i.e. an election with substantially lower turnout. Even if the design of our study does not allow us to make any certain causal claims, the quality and size of the data makes us believe that we would have discovered an effect if it existed.

It is still, however, possible that mock elections carried out in other electoral contexts or in other ways might have an effect on voter turnout. In countries with bigger hurdles to voting, the mock election might provide vital skills that facilitate participation, as might mock elections with more intensive learning activities stretched over a longer time period (see Dassonneville et al. 2012). We hope that future research will examine mock elections in other countries to see if our results can be generalised.

It should also be noted that mock elections might lead to other outcomes worth pursuing or have other values. Some previous studies have for example found that mock elections can help improve students' internal efficacy and their political knowledge (Hansen et al., 2015; Hansen, 2017). Mock elections could also be seen as a way for young people to express themselves politically, even if the election results do not have any direct consequences and, at least in the Swedish case, gets limited media attention. However, in a qualitative study by Borge (2018), students said that they saw the mock election as an assignment rather than an opportunity to voluntarily express their political views. 
In conclusion, we do not claim that mock elections do not have merit and that schools should refrain from organising them in the future. We only state that our results do not support the view that mock elections improve voter turnout, and we therefore suggest that the rationale for carrying them out should be found elsewhere.

\section{About the authors}

Richard Öhrvall is a postdoctoral researcher at Centre for Municipal Studies (CKS), Linköping University, and a researcher at Research Institute of Industrial Economics (IFN). His research interests include political representation and participation and social trust. His previous work has appeared in journals such as Local Government Studies, Electoral Studies, Government and Opposition, Journal of Comparative Economics, and Public Choice. Postal Address: Richard Öhrvall, Centre for Municipal Studies, Linköping University, SE-581 83 Linköping, Sweden. E-mail: richard.ohrvall@liu.se

Sven Oskarsson is Professor in the Department of Government at Uppsala University. His research interests include political representation and participation and social science genomics. His previous work has appeared in journals such as American Political Science Review, American Journal of Political Science, Political Behavior, Nature, and Behavior Genetics. Postal address: Sven Oskarsson, Department of Government, Uppsala University, Box 514, SE-751 20 Uppsala, Sweden. E-mail: sven.oskarsson@statsvet.uu.se

\section{Acknowledgements}

Financial support from the Swedish Research Council is gratefully acknowledged. The authors would also like to thank Jan Teorell, Anders Westholm, the participants of the Swepop seminar at Swepsa 2016, and the three anonymous reviewers and the editors of Politics for their valuable comments. In addition, we would like to thank Statistics Sweden and the Swedish Agency for Youth and Civil Society for providing data. 


\section{References}

Bechtel, M. M., D. Hangartner, and L. Schmid (2018). Compulsory Voting, Habit Formation, and Political Participation. The Review of Economics and Statistics $100(3), 467-476$.

Berinsky, A. J. and G. S. Lenz (2011). Education and Political Participation. Political Behavior 33(3), 357-373.

Bhatti, Y., K. M. Hansen, and H. Wass (2016). First-time boost beats experience. Electoral Studies 41, 151-158.

Blais, A. (2007). Turnout in elections. In R. J. Dalton and H.-D. Klingemann (Eds.), The Oxford Handbook of Political Behavior, pp. 621-635. Oxford: Oxford University Press.

Borge, J. A. Ø. (2016). Creating Democratic Citizens? Ph.D., University of Bergen, Bergen.

Borge, J. A. Ø. (2017). Tuning in to formal politics. Politics 37(2), 201-214.

Borge, J. A. O. (2018). "Am I a politics person?". JSSE - Journal of Social Science Education, 63-74.

Campbell, A., P. E. Converse, W. E. Miller, and D. E. Stokes (1960). The American Voter. The American Voter. New York: Wiley.

Coppock, A. and D. P. Green (2016). Is Voting Habit Forming? American Journal of Political Science 60(4), 1044-1062.

Dassonneville, R., E. Quintelier, M. Hooghe, and E. Claes (2012). The Relation Between Civic Education and Political Attitudes and Behavior. Applied Developmental Science 16(3), 140-150.

de Groot, I. (2017). Mock Elections in Civic Education. Journal of Social Science Education 16(3), 85-96.

Deitz, J. L. and K. Boeckelman (2012). Simulating 2008: A Mock Presidential Election's Impact on Civic Engagement. PS: Political Science \& Politics 45(04), 743-747.

Dinas, E. (2012). The Formation of Voting Habits. Journal of Elections, Public Opinion 83 Parties 22(4), 431-456. 
Franklin, M. N. (2004). Voter Turnout and the Dynamics of Electoral Competition in Established Democracies since 1945. Cambridge: Cambridge University Press.

Gäbler, S., N. Potrafke, and F. Rösel (2017). Compulsory Voting, Voter Turnout and Asymmetrical Habit-formation. CESinfo Working Papers 6764, München.

Geboers, E., F. Geijsel, W. Admiraal, and G. ten Dam (2013). Review of the effects of citizenship education. Educational Research Review 9, 158-173.

Gerber, A. S., D. P. Green, and R. Shachar (2003). Voting May Be HabitForming. American Journal of Political Science 47(3), 540-550.

Hansen, J. H. (2017). Skolevalg 2017. Technical Report 2017/2, University of Copenhagen, Copenhagen.

Hansen, J. H., K. M. Hansen, and K. Levinsen (2015). Skolevalg 2015. WorkingPaper, Center for Valg og Partier, Institut for Statskundskab, Københavns Universitet.

Holmberg, S. and H. Oscarsson (2004). Väljare: svenskt väljarbeteende under 50 år. Stockholm: Norstedts Juridik.

Jorsäter, M. and E. Snölilja (2018). Hur gick det för eleverna som var obehöriga till gymnasieskolan? Technical report, Statistics Sweden, Stockholm.

Kahne, J. E. and S. E. Sporte (2008). Developing Citizens. American Educational Research Journal 45(3), 738-766.

Leighley, J. E. and J. Nagler (2014). Who Votes Now? Princeton: Princeton University Press.

Lijphart, A. (1997). Unequal Participation: Democracy's Unresolved Dilemma. The American Political Science Review 91(1), 1-14.

Lindgren, K.-O., S. Oskarsson, and C. T. Dawes (2017). Can Political Inequalities Be Educated Away? American Journal of Political Science $61(1), 222-236$.

Lindgren, K.-O., S. Oskarsson, and M. Persson (2019). Enhancing Electoral Equality. American Political Science Review 113(1), 108-122. 
Meredith, M. (2009). Persistence in Political Participation. Quarterly Journal of Political Science 4(3), 187-209.

MUCF (2015). Öva och ta ställning: En utvärdering av arbetet med skolvalen 2014. Technical report, The Swedish Agency for Youth and Civil Society.

Neundorf, A., R. G. Niemi, and K. Smets (2016). The Compensation Effect of Civic Education on Political Engagement. Political Behavior 38(4), 921-949.

OECD (2010). PISA 2009 Results. Technical report, OECD, Paris.

Öhrvall, R. (2015). Voter Turnout. In J. Pierre (Ed.), The Oxford Handbook of Swedish Politics, pp. 229-245. Oxford: Oxford University Press.

Persson, M. (2014). Testing the Relationship Between Education and Political Participation Using the 1970 British Cohort Study. Political Behavior 36(4), 877-897.

Persson, M. (2015a). Classroom Climate and Political Learning. Political Psychology 36(5), 587-601.

Persson, M. (2015b). Education and Political Participation. British Journal of Political Science 45(03), 689-703.

Plutzer, E. (2002). Becoming a habitual voter. American Political Science Review 96(1), 41-56.

Rosenstone, S. J. and J. M. Hansen (1993). Mobilization, Participation, and Democracy in America. New York: Macmillan.

Schlozman, K. L., S. Verba, and H. E. Brady (2012). The Unheavenly Chorus. Princeton, N.J. ;: Princeton University Press.

Solijonov, A. (2016). Voter Turnout Trends around the World. Technical report, IDEA, Stockholm.

Syvertsen, A. K., M. D. Stout, C. A. Flanagan, D. L. Mitra, M. B. Oliver, and S. S. Sundar (2009). Using Elections as Teachable Moments. American Journal of Education 116(1), 33-67.

Torney-Purta, J. (2002). The School's Role in Developing Civic Engagement. Applied Developmental Science 6(4), 203-212.

Ungdomsstyrelsen (2007). Skolval 2006. Report 16, Ungdomsstyrelsen, Stockholm. 
Ungdomsstyrelsen (2011). Skolval 2010. Technical report, Ungdomsstyrelsen, Stockholm.

Verba, S. and N. H. Nie (1972). Participation in America. New York: Harper and Row.

Verba, S., K. L. Schlozman, and H. E. Brady (1995). Voice and Equality. Cambridge, Mass.: Harvard University Press.

Wolfinger, R. E. and S. J. Rosenstone (1980). Who Votes? New Haven: Yale U.P. 


\title{
Online Appendix to "Practice Makes Voters? Effects of Student Mock Elections on Turnout"
}

\author{
Richard Öhrvall * $\quad$ Sven Oskarsson ${ }^{\dagger}$
}

August 26, 2019

\section{Contents}

\begin{tabular}{ll}
\hline Data availability & 3 \\
\hline
\end{tabular}

\begin{tabular}{ll}
\hline Variables and data sources & 3
\end{tabular}

\begin{tabular}{|ll}
\hline Auxiliary results & 6 \\
\hline
\end{tabular}

\footnotetext{
${ }^{*}$ Linköping University and Research Institute of Industrial Economics (IFN) richard.ohrvall@liu.se

${ }^{\dagger}$ Uppsala University and UCLS

sven.oskarsson@statsvet.uu.se
} 


\section{List of Tables}

A1 Summary statistics, students enrolled in 1998 . . . . . . . . 7

A2 $\quad$ Summary statistics, students enrolled in 2002 . . . . . . . . . 8

A3 $\quad$ Summary statistics, students enrolled in 2006 . . . . . . . . . . 9

A4 Summary statistics, students enrolled in election year 2010 . . 10

A5 Turnout in European Parliament election 2009 among students enrolled 1998-2006. OLS regressions . . . . . . . . . . . . . 11

A6 Turnout in European Parliament election 2009 among students enrolled in election years 1998-2006, by family SES quartile.

OLS regressions . . . . . . . . . . . . . . . . . . 12

A7 Turnout in European Parliamentary election 2009 among students enrolled in different election years 1998-2006. OLS re-

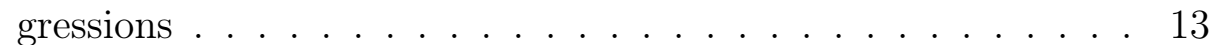

A8 Turnout in parliamentary election 2010 among students enrolled in election years 1998-2010. Logit regressions . . . . . . 14

A9 Turnout in parliamentary election 2010 among students enrolled in election years 1998-2010, by family SES quartile. Logit regressions $\ldots \ldots \ldots \ldots \ldots \ldots$

A10 Turnout in parliamentary election 2010 among students enrolled in different election years 1998-2010. Logit regressions . 16

A11 Turnout in parliamentary election 2010 among students enrolled in election years 1998-2010, by quartiles based on average school GPA. OLS regressions . . . . . . . . . . . 17

A12 Turnout in parliamentary election 2010 among students enrolled in election years 1998-2010, by quartiles based on average family SES in school. OLS regressions . . . . . . . . . . 18 


\section{Data availability}

In this article, we use individual level information obtained from various administrative registers. The data are stored on an encrypted server at Statistics Sweden and all our analysis have been conducted through a remote desktop application. We are under contractual obligation not to disseminate these data to other individuals. For interested researchers there are, however, two ways to get access to the administrative data used in this paper for replication purposes. The first possibility is to order the data directly from Statistics Sweden. Currently, Statistics Sweden requires that researchers obtain permission from a Swedish Ethical Review Board before data can be ordered (a description, in Swedish, of how to order data from Statistics Sweden is available at: https://www.scb.se/en/services/ guidance-for-researchers-and-universities/). We will also make available a complete list of the variables that we ordered from Statistics Sweden for this project.

The second possibility to replicate our analyses for interested researchers is to come to Uppsala University and reanalyse these data through the same remote server system that we used for our analyses. Any researcher interested in using this option needs to contact us before coming to Sweden so that we can arrange with Statistics Sweden that the researcher is temporarily added to our research team, which is required in order to get access to the remote server system.

\section{Variables and data sources}

In the main analysis we make use of data from various administrative registers. In this subsection we describe this data in somewhat more detail.

Birth month - Information is retrieved from the Swedish Population Register.

Female - Equal to 1 if female. Information is retrieved from the Swedish Population Register.

Immigrant background - Statistics Sweden's standard variable measuring immigration background. The variable is classified into four categories: (i) born in Sweden and both parents born Sweden; (ii) born in Sweden and one of the parents born abroad; (iii) born in Sweden and both parents born abroad; and (iv) born abroad and both parents born abroad. Information is retrieved from the Swedish Population Register. 
GPA - Grade point average from compulsory school. The grades in each subjected is recorded on a scale from 0 to 20 with higher number indicating better grades. Information is retrieved from the Upper Secondary School Application Record.

School - Categorical variable indicating which upper secondary school the individual was enrolled. Information is retrieved from information in the Upper Secondary School Application Record.

School programme - Categorical variable indicating which of the 18 national and 5 introductory programmes the individual was enrolled. Information is retrieved from information in the Upper Secondary School Application Record.

Mock election - Dummy variable indicating whether a school arranged mock elections in connection to each of the four parliamentary elections in 1998-2010. Information is retrieved from the Swedish Agency for Youth and Civil Society (MUCF by Swedish acronym).

Turnout EP - Turnout in the 2009 EP election. Information retrieved from Statistics Sweden.

Turnout general — Turnout in the 2010 general election. Information retrieved from Statistics Sweden.

Parental turnout EP - Average turnout among the parents in the 2009 EP election. Information retrieved from Statistics Sweden.

Parental turnout general - Average turnout among the parents in the 2010 general election. Information retrieved from Statistics Sweden.

Parental income - Average labor income of mother and father. Information is retrieved from the 1985 census.

Parental education - Highest education, in years, of mother and father. Information is retrieved from the 1985 census.

Parental occupational status - This variable is based on the occupational codes for mothers and fathers in the 1985 census (NYK-85). We converted NYK-85 codes into ISCO-88 format by using conversion keys developed by Statistics Sweden and Erik Bihagen (2007). In the next step, the occupational codes for mothers and fathers were translated into three different, but highly correlated, measures of occupational status: the International Socio-Economic Index (ISEI, Ganzeboom et al., 1992), the Standard International Occupational Prestige Scale (SIOPS, Treiman, 1977), and the International Cambridge Scale (ICAMS, Meraviglia et al., 2016; Prandy and Jones, 2001). 
The SIOPS scale was constructed by Treiman (1977) through averaging the prestige scores of about 60 national prestige scales and then mapping the resulting scores into ISCO-68 occupational titles. The ISEI indicator is based on a different rationale and attempts to capture the process that translates educational credentials into income Ganzeboom et al., 1992). More technically, the measure was constructed through an optimal scaling procedure in such a way as to maximise the role of occupation as a mediator between education and income. Lastly, the ICAMS score uses detailed information on inter-occupational marriage patterns to statistically estimate the "social distance" between different types of occupations (Prandy and Jones, 2001). The indicator thus measures occupational stratification. For reasons of international comparison, we here use the international CAMSIS scale developed by Meraviglia et al. (2016) based on information available in surveys of the International Social Survey Programme (ISSP) for the years 2001 to 2007.

The code to translate census occupational codes into ICAMS, ISEI, and SIOPS was downloaded from http://www.harryganzeboom.nl/isco88/ index.htm. We then computed the occupational status of fathers and mothers, respectively, as the average of these three indicators (they all vary between 0 and 100). Finally, parental occupational status is the maximum of father's and mother's occupational status. For a small number of individuals that have two non-employed parents, parental occupational status have been set to its sample minimum value.

Family SES - In this study we use a measure of socioeconomic status that is closely related to the PISA index of economic, social, and cultural status (ESCS), developed by the OECD. This is a simple average of parental earnings, parental education, and parental occupational status. All items are assigned the same weight in calculating the SES index and is based on the two indicators for which data is available if information on one of the indicators in the index is missing. To adjust for differences in scales between the variables, all three sub-items were initially standardised to have a mean of 0 and a standard deviation of 1 in the sample under study. Parental earnings were top coded at the 99th percentile before being standardised. The scale reliability of the resulting index is .79.

Whereas information on parental education and labor income are gathered directly from the registers our measure of occupational status is based on census occupation codes. More precisely, we use the occupation codes to compute three well-known measures of occupational status: the International Socio-Economic Index (ISEI, Ganzeboom et al., 1992)), the Standard International Occupational Prestige Scale (SIOPS, Treiman, 
1977), and the International Cambridge Scale (ICAMS, Meraviglia et al., 2016; Prandy and Jones, 2001)! 1 As shown by Meraviglia et al. (2016), despite the differences in conceptual underpinnings these three measures are very highly correlated and appear to reflect a single underlying dimension. We therefore use the average of these three indicators to measure mothers' and fathers' occupational statuses. The scale reliability of this index is .96 for fathers and .93 for mothers. For a small number of individuals that have two non-employed parents, parental occupational status has been set at its sample minimum value.

School GPA - Average GPA from the ninth grade at the school level.

School parental turnout EP - Average parental turnout in the 2009 EP election at the school level.

School parental turnout general - Average parental turnout in the 2010 general election at the school level.

School family SES - Average family SES at the school level.

\section{Auxiliary results}

In this subsection we provide some auxiliary summary statistics and regression results. Tables A1, A2, A3, and A4 present separate summary statistics for students enrolled in upper secondary school in each of the four election years 1998, 2002, 2006, and 2010. Tables A5, A6, and A7 present replications of the main results using turnout in the $2009 \mathrm{EP}$ election as the outcome. Tables A8, A9, and A10 provide results from models using a logit estimator. Finally, we have divided our sample into quartiles depending on the average GPA and family SES at the school level, respectively, and estimated a model for each quartile. The results of those models are presented in Tables A11 and $\mathrm{A} 12$.

\footnotetext{
${ }^{1}$ The code for translating census occupation codes into ICAMS, ISEI, and SIOPS was downloaded from http://www.harryganzeboom.nl/isco88/index.htm.
} 
Table A1: Summary statistics, students enrolled in 1998

\begin{tabular}{|c|c|c|c|c|c|}
\hline & Obs. & Mean & Std. Dev. & Min & Max \\
\hline \multicolumn{6}{|c|}{ a) All students } \\
\hline Turnout 2010 general election & 230,234 & .866 & .340 & 0 & 1 \\
\hline Turnout 2009 EP election & 228,659 & .465 & .499 & 0 & 1 \\
\hline Female & 240,746 & .503 & .500 & 0 & 1 \\
\hline GPA (std.) & 237,690 & .013 & .988 & -5.167 & 3.127 \\
\hline Parents voted (general) & 225,889 & .912 & .246 & 0 & 1 \\
\hline Parents voted (EP) & 225,510 & .537 & .451 & 0 & 1 \\
\hline Family SES & 240,598 & -.146 & .765 & -1.933 & 2.725 \\
\hline School: Parents voted (general) & 240,746 & .910 & .032 & .4 & 1 \\
\hline School: Parents voted (EP) & 240,737 & .527 & .091 & 0 & .869 \\
\hline School: Family SES & 240,746 & -.092 & .279 & -1.576 & 1.130 \\
\hline School: GPA (std.) & 240,746 & .024 & .408 & -5.167 & 1.504 \\
\hline \multicolumn{6}{|c|}{ b) Students at schools with mock elections } \\
\hline Turnout 2010 general election & 38,074 & .871 & .335 & 0 & 1 \\
\hline Turnout 2009 EP election & 37,239 & .475 & .499 & 0 & 1 \\
\hline Female & 39,631 & .506 & .500 & 0 & 1 \\
\hline GPA (std.) & 39,178 & .059 & .949 & -5.167 & 2.721 \\
\hline Parents voted (general) & 37,328 & .913 & .246 & 0 & 1 \\
\hline Parents voted (EP) & 36,370 & .544 & .451 & 0 & 1 \\
\hline Family SES & 39,607 & -.133 & .762 & -1.933 & 2.559 \\
\hline School: Parents voted (general) & 39,631 & .913 & .029 & .690 & .958 \\
\hline School: Parents voted (EP) & 39,631 & .542 & .076 & .314 & .749 \\
\hline School: Family SES & 39,631 & -.133 & .241 & -.930 & .574 \\
\hline School: GPA (std.) & 39,631 & .059 & .263 & -1.127 & .876 \\
\hline \multicolumn{6}{|c|}{ c) Students at schools without mock elections } \\
\hline Turnout 2010 general election & 192,160 & .865 & .342 & 0 & 1 \\
\hline Turnout 2009 EP election & 191,420 & .464 & .499 & 0 & 1 \\
\hline Female & 210,115 & .502 & .500 & 0 & 1 \\
\hline GPA (std.) & 198,512 & .004 & .996 & -5.167 & 3.127 \\
\hline Parents voted (general) & 188,561 & .912 & .246 & 0 & 1 \\
\hline Parents voted (EP) & 189,140 & .536 & .451 & 0 & 1 \\
\hline Family SES & 200,991 & -.149 & .766 & -1.933 & 2.725 \\
\hline School: Parents voted (general) & 201,115 & .909 & .033 & .4 & 1 \\
\hline School: Parents voted (EP) & 201,106 & .524 & .093 & 0 & .869 \\
\hline School: Family SES & 201,115 & -.084 & .285 & -1.576 & 1.130 \\
\hline School: GPA (std.) & 201,115 & .017 & .430 & -5.167 & 1.504 \\
\hline
\end{tabular}

\footnotetext{
Note: Variables with 'School' prefix refer to school averages. GPA refers to average grade in class 9 , standardised for each year. Variables regarding turnout refer to voting in the 2010 parliamentary election (general) and the 2009 European Parliament election (EP). Family SES is an average of parental earnings, parental education, and parental occupational status, where all items initially have been standardised to have a mean of 0 and a standard deviation of 1 .
} 
Table A2: Summary statistics, students enrolled in 2002

\begin{tabular}{|c|c|c|c|c|c|}
\hline & Obs. & Mean & Std. Dev. & Min & Max \\
\hline \multicolumn{6}{|c|}{ a) All students } \\
\hline Turnout 2010 general election & 267,765 & .825 & .380 & 0 & 1 \\
\hline Turnout 2009 EP election & 265,531 & .411 & .492 & 0 & 1 \\
\hline Female & 279,594 & .491 & .500 & 0 & 1 \\
\hline GPA (std.) & 276,193 & .002 & .996 & -4.868 & 2.314 \\
\hline Parents voted (general) & 263,857 & .903 & .254 & 0 & 1 \\
\hline Parents voted $(\mathrm{EP})$ & 263,691 & .512 & .449 & 0 & 1 \\
\hline Family SES & 279,482 & -.041 & .784 & -1.933 & 3.347 \\
\hline School: Parents voted (general) & 279,593 & .903 & .031 & .5 & 1 \\
\hline School: Parents voted (EP) & 279,593 & .503 & .092 & 0 & 1 \\
\hline School: Family SES & 279,594 & .008 & .276 & -1.432 & 1.392 \\
\hline School: GPA (std.) & 279,593 & .001 & .436 & -3.596 & 1.504 \\
\hline \multicolumn{6}{|c|}{ b) Students at schools with mock elections } \\
\hline Turnout 2010 general election & 142,155 & .828 & .377 & 0 & 1 \\
\hline Turnout 2009 EP election & 141,474 & .420 & .494 & 0 & 1 \\
\hline Female & 148,196 & .500 & .500 & 0 & 1 \\
\hline GPA (std.) & 146,375 & .052 & .984 & -4.868 & 2.253 \\
\hline Parents voted (general) & 140,069 & .904 & .254 & 0 & 1 \\
\hline Parents voted (EP) & 140,625 & .520 & .450 & 0 & 1 \\
\hline Family SES & 148,122 & -.022 & .796 & -1.933 & 3.347 \\
\hline School: Parents voted (general) & 148,196 & .904 & .033 & .760 & .980 \\
\hline School: Parents voted (EP) & 148,196 & .513 & .091 & .226 & .806 \\
\hline School: Family SES & 148,196 & .027 & .281 & -.715 & 1.007 \\
\hline School: GPA (std.) & 148,196 & .052 & .400 & -2.854 & 1.467 \\
\hline \multicolumn{6}{|c|}{ c) Students at schools without mock elections } \\
\hline Turnout 2010 general election & 125,610 & .821 & .384 & 0 & 1 \\
\hline Turnout 2009 EP election & 124,057 & .401 & .490 & 0 & 1 \\
\hline Female & 131,398 & .481 & .500 & 0 & 1 \\
\hline GPA (std.) & 129,818 & -.054 & 1.006 & -4.868 & 2.314 \\
\hline Parents voted (general) & 123,788 & .902 & .254 & 0 & 1 \\
\hline Parents voted (EP) & 123,066 & .503 & .448 & 0 & 1 \\
\hline Family SES & 131,360 & -.062 & .768 & -1.933 & 3.055 \\
\hline School: Parents voted (general) & 131,397 & .902 & .029 & .5 & 1 \\
\hline School: Parents voted (EP) & 131,397 & .491 & .093 & 0 & 1 \\
\hline School: Family SES & 131,398 & -.013 & .269 & -1.432 & 1.392 \\
\hline School: GPA (std.) & 131,397 & -.057 & .466 & -3.596 & 1.504 \\
\hline
\end{tabular}

Note: See Table A1 for information about the variables. 
Table A3: Summary statistics, students enrolled in 2006

\begin{tabular}{|c|c|c|c|c|c|}
\hline & Obs. & Mean & Std. Dev. & Min & Max \\
\hline \multicolumn{6}{|c|}{ a) All students } \\
\hline Turnout 2010 general election & 307,185 & .804 & .397 & 0 & 1 \\
\hline Turnout 2009 EP election & 304,070 & .417 & .493 & 0 & 1 \\
\hline Female & 322,278 & .494 & .500 & 0 & 1 \\
\hline GPA (std.) & 318,343 & .001 & .999 & -4.186 & 2.189 \\
\hline Parents voted (general) & 305,629 & .902 & .252 & 0 & 1 \\
\hline Parents voted (EP) & 305,089 & .497 & .447 & 0 & 1 \\
\hline Family SES & 322,168 & .063 & .789 & -1.933 & 3.615 \\
\hline School: Parents voted (general) & 322,278 & .902 & .032 & 0 & 1 \\
\hline School: Parents voted (EP) & 322,277 & .499 & .095 & 0 & .808 \\
\hline School: Family SES & 322,278 & .018 & .278 & -1.564 & 1.428 \\
\hline School: GPA (std.) & 322,277 & -.013 & .452 & -3.596 & 1.504 \\
\hline \multicolumn{6}{|c|}{ b) Students at schools with mock elections } \\
\hline Turnout 2010 general election & 207,061 & .809 & .393 & 0 & 1 \\
\hline Turnout 2009 EP election & 204,037 & .424 & .494 & 0 & 1 \\
\hline Female & 218,204 & .502 & .500 & 0 & 1 \\
\hline GPA (std.) & 215,643 & .051 & .987 & -4.186 & 2.189 \\
\hline Parents voted (general) & 205,920 & .903 & .250 & 0 & 1 \\
\hline Parents voted (EP) & 204,792 & .501 & .448 & 0 & 1 \\
\hline Family SES & 218,130 & .081 & .795 & -1.933 & 3.377 \\
\hline School: Parents voted (general) & 218,204 & .903 & .031 & .750 & .972 \\
\hline School: Parents voted (EP) & 218,204 & .504 & .094 & .226 & .787 \\
\hline School: Family SES & 218,204 & .029 & .281 & -.732 & 1.036 \\
\hline School: GPA (std.) & 218,204 & .034 & .411 & -2.854 & 1.504 \\
\hline \multicolumn{6}{|c|}{ c) Students at schools without mock elections } \\
\hline Turnout 2010 general election & 100,124 & .795 & .404 & 0 & 1 \\
\hline Turnout 2009 EP election & 100,033 & .403 & .491 & 0 & 1 \\
\hline Female & 104,074 & .478 & .500 & 0 & 1 \\
\hline GPA (std.) & 102,700 & -.102 & 1.016 & -4.088 & 2.189 \\
\hline Parents voted (general) & 99,709 & .899 & .254 & 0 & 1 \\
\hline Parents voted (EP) & 100,297 & .487 & .446 & 0 & 1 \\
\hline Family SES & 104,038 & .026 & .774 & -1.933 & 3.615 \\
\hline School: Parents voted (general) & 104,074 & .901 & .033 & 0 & 1 \\
\hline School: Parents voted (EP) & 104,073 & .490 & .095 & 0 & .808 \\
\hline School: Family SES & 104,074 & -.005 & .271 & -1.564 & 1.428 \\
\hline School: GPA (std.) & 104,073 & -.113 & .514 & -3.596 & 1.467 \\
\hline
\end{tabular}

Note: See Table A1 for information about the variables. 
Table A4: Summary statistics, students enrolled in election year 2010

\begin{tabular}{|c|c|c|c|c|c|}
\hline & Obs. & Mean & Std. Dev. & Min & Max \\
\hline \multicolumn{6}{|c|}{ a) All students } \\
\hline Turnout 2010 general election & 79,361 & .886 & .318 & 0 & 1 \\
\hline Female & 84,535 & .484 & .500 & 0 & 1 \\
\hline GPA (std.) & 83,286 & -.047 & 1.046 & -4.382 & 2.189 \\
\hline Parents voted (general) & 79,348 & .907 & .244 & 0 & 1 \\
\hline Parents voted (EP) & 79,105 & .465 & .447 & 0 & 1 \\
\hline Family SES & 84,516 & .178 & .829 & -1.933 & 3.786 \\
\hline School: Parents voted (general) & 84,535 & .902 & .034 & 0 & 1 \\
\hline School: Parents voted (EP) & 84,532 & .496 & .100 & 0 & 1 \\
\hline School: Family SES & 84,535 & .033 & .286 & -1.528 & 1.428 \\
\hline School: GPA (std.) & 84,535 & -.027 & .475 & -3.716 & 1.504 \\
\hline \multicolumn{6}{|c|}{ b) Students at schools with mock elections } \\
\hline Turnout 2010 general election & 54,038 & .894 & .308 & 0 & 1 \\
\hline Female & 57,878 & .492 & .500 & 0 & 1 \\
\hline GPA (std.) & 57,025 & .019 & 1.041 & -4.382 & 2.189 \\
\hline Parents voted (general) & 54,055 & .911 & .240 & 0 & 1 \\
\hline Parents voted (EP) & 54,011 & .476 & .449 & 0 & 1 \\
\hline Family SES & 57,862 & .206 & .837 & -1.933 & 3.786 \\
\hline School: Parents voted (general) & 57,878 & .905 & .032 & .5 & 1 \\
\hline School: Parents voted (EP) & 57,878 & .506 & .098 & .226 & .806 \\
\hline School: Family SES & 57,878 & .049 & .291 & -.732 & 1.036 \\
\hline School: GPA (std.) & 57,878 & .029 & .451 & -3.428 & 1.504 \\
\hline \multicolumn{6}{|c|}{ c) Students at schools without mock elections } \\
\hline Turnout 2010 general election & 25,323 & .867 & .339 & 0 & 1 \\
\hline Female & 26,657 & .466 & .499 & 0 & 1 \\
\hline GPA (std.) & 26,261 & -.191 & 1.043 & -4.381 & 2.157 \\
\hline Parents voted (general) & 25,293 & .897 & .254 & 0 & 1 \\
\hline Parents voted (EP) & 25,094 & .440 & .443 & 0 & 1 \\
\hline Family SES & 26,654 & .116 & .809 & -1.933 & 3.212 \\
\hline School: Parents voted (general) & 26,657 & .897 & .038 & 0 & 1 \\
\hline School: Parents voted (EP) & 26,654 & .473 & .100 & 0 & 1 \\
\hline School: Family SES & 26,657 & -.003 & .270 & -1.528 & 1.428 \\
\hline School: GPA (std.) & 26,657 & -.149 & .503 & -3.716 & 1.346 \\
\hline
\end{tabular}

Note: See Table A1 for information about the variables. 
Table A5: Turnout in European Parliament election 2009 among students enrolled 1998-2006. OLS regressions

\begin{tabular}{|c|c|c|c|c|}
\hline & A & B & $\mathrm{C}$ & $\mathrm{D}$ \\
\hline Mock election & $\begin{array}{l}0.0167^{* * *} \\
(0.00627)\end{array}$ & $\begin{array}{c}-0.00129 \\
(0.00222)\end{array}$ & $\begin{array}{l}0.000482 \\
(0.00235)\end{array}$ & $\begin{array}{c}-0.000311 \\
(0.00202)\end{array}$ \\
\hline School: Parents voted (general) & & $\begin{array}{l}-0.0352 \\
(0.0425)\end{array}$ & & $\begin{array}{c}-0.160^{* * *} \\
(0.0409)\end{array}$ \\
\hline School: Parents voted (EP) & & $\begin{array}{l}0.793^{* * *} \\
(0.0239)\end{array}$ & & $\begin{array}{l}0.377^{* * *} \\
(0.0226)\end{array}$ \\
\hline School: Family SES & & $\begin{array}{c}0.0328^{* * *} \\
(0.00847)\end{array}$ & & $\begin{array}{c}0.00829 \\
(0.00780)\end{array}$ \\
\hline School: GPA (std.) & & $\begin{array}{l}0.0264^{* * *} \\
(0.00481)\end{array}$ & & $\begin{array}{c}-0.0461^{* * *} \\
(0.00393)\end{array}$ \\
\hline Parents voted (general) & & & $\begin{array}{l}0.0294^{* * *} \\
(0.00214)\end{array}$ & $\begin{array}{l}0.0301^{* * *} \\
(0.00212)\end{array}$ \\
\hline Parents voted (EP) & & & $\begin{array}{c}0.354^{* * *} \\
(0.00239)\end{array}$ & $\begin{array}{c}0.349^{* * *} \\
(0.00238)\end{array}$ \\
\hline Female & & & $\begin{array}{c}-0.0192^{* * *} \\
(0.00141)\end{array}$ & $\begin{array}{c}-0.0203^{\text {*** }} \\
(0.00134)\end{array}$ \\
\hline Family SES & & & $\begin{array}{c}0.0216^{* * *} \\
(0.00111)\end{array}$ & $\begin{array}{c}0.0162^{* * *} \\
(0.000934)\end{array}$ \\
\hline GPA (std.) & & & $\begin{array}{l}0.0522^{* * *} \\
(0.00149)\end{array}$ & $\begin{array}{l}0.0548^{* * *} \\
(0.00104)\end{array}$ \\
\hline Birth year fixed effects & $\checkmark$ & $\checkmark$ & $\checkmark$ & $\checkmark$ \\
\hline School programme fixed effects & & & $\checkmark$ & $\checkmark$ \\
\hline Immigration background fixed effects & & & $\checkmark$ & $\checkmark$ \\
\hline$N$ & 750,174 & 750,174 & 750,174 & 750,174 \\
\hline
\end{tabular}

Notes: Standard errors in parentheses. The models are estimated using pooled data of students enrolled at upper-secondary schools in 1998, 2002, and 2006. Variables with 'School' prefix refer to averages at school level. Variables regarding turnout refer to voting in the 2010 parliamentary election (general) and the 2009 European Parliament election (EP). Family SES is an average of parental earnings, parental education, and parental occupational status, where all items initially have been standardised to have a mean of 0 and a standard deviation of 1. GPA refers to average grade in class 9, standardised for each year. School programme refers to the 18 national and 5 introductory programmes available at upper-secondary schools. Immigration background is classified into four categories: the first three refer to people born in Sweden with both, only one, or none of their parents born in Sweden, and the fourth category contain foreign-born persons. 
Table A6: Turnout in European Parliament election 2009 among students enrolled in election years 1998-2006, by family SES quartile. OLS regressions

\begin{tabular}{|c|c|c|c|c|}
\hline & Q1 & Q2 & Q3 & Q4 \\
\hline Mock elections & $\begin{array}{c}-0.00298 \\
(0.00260)\end{array}$ & $\begin{array}{c}-0.00372 \\
(0.00265)\end{array}$ & $\begin{array}{c}0.000143 \\
(0.00285)\end{array}$ & $\begin{array}{c}0.00673^{*} \\
(0.00347)\end{array}$ \\
\hline School: Parents voted (general) & $\begin{array}{l}0.0826^{*} \\
(0.0496)\end{array}$ & $\begin{array}{c}-0.203^{* * *} \\
(0.0545)\end{array}$ & $\begin{array}{c}-0.193^{* * *} \\
(0.0597)\end{array}$ & $\begin{array}{c}-0.251^{* * *} \\
(0.0852)\end{array}$ \\
\hline School: Parents voted (EP) & $\begin{array}{l}0.275^{* * *} \\
(0.0277)\end{array}$ & $\begin{array}{l}0.372^{* * *} \\
(0.0283)\end{array}$ & $\begin{array}{l}0.369^{* * *} \\
(0.0332)\end{array}$ & $\begin{array}{l}0.507^{* * *} \\
(0.0438)\end{array}$ \\
\hline School: GPA (std.) & $\begin{array}{c}-0.0387^{* * *} \\
(0.00509)\end{array}$ & $\begin{array}{c}-0.0563^{* * *} \\
(0.00551)\end{array}$ & $\begin{array}{c}-0.0504^{* * *} \\
(0.00493)\end{array}$ & $\begin{array}{c}-0.0434^{\text {*** }} \\
(0.00706)\end{array}$ \\
\hline Female & $\begin{array}{c}-0.0186^{* * *} \\
(0.00242)\end{array}$ & $\begin{array}{c}-0.0216^{* * *} \\
(0.00253)\end{array}$ & $\begin{array}{c}-0.0222^{* * *} \\
(0.00250)\end{array}$ & $\begin{array}{c}-0.0200^{* * *} \\
(0.00253)\end{array}$ \\
\hline Parents voted (general) & $\begin{array}{l}0.0381^{* * *} \\
(0.00302)\end{array}$ & $\begin{array}{c}0.0365^{* * *} \\
(0.00369)\end{array}$ & $\begin{array}{l}0.0363^{* * *} \\
(0.00530)\end{array}$ & $\begin{array}{c}0.0186^{* *} \\
(0.00803)\end{array}$ \\
\hline Parents voted (EP) & $\begin{array}{c}0.318^{* * *} \\
(0.00334)\end{array}$ & $\begin{array}{c}0.347^{* * *} \\
(0.00302)\end{array}$ & $\begin{array}{c}0.361^{* * *} \\
(0.00342)\end{array}$ & $\begin{array}{c}0.370^{* * *} \\
(0.00380)\end{array}$ \\
\hline GPA (std.) & $\begin{array}{l}0.0469^{* * *} \\
(0.00152)\end{array}$ & $\begin{array}{c}0.0556^{* * *} \\
(0.00152)\end{array}$ & $\begin{array}{l}0.0614^{* * *} \\
(0.00164)\end{array}$ & $\begin{array}{l}0.0567^{* * *} \\
(0.00209)\end{array}$ \\
\hline Birth year fixed effects & $\checkmark$ & $\checkmark$ & $\checkmark$ & $\checkmark$ \\
\hline School programme fixed effects & $\checkmark$ & $\checkmark$ & $\checkmark$ & $\checkmark$ \\
\hline Immigration background fixed effects & $\checkmark$ & $\checkmark$ & $\checkmark$ & $\checkmark$ \\
\hline$N$ & 190,272 & 193,041 & 191,158 & 175,703 \\
\hline
\end{tabular}

${ }^{*} p<0.10,{ }^{* *} p<0.05,{ }^{* * *} p<0.01$

Notes: Standard errors in parentheses. Students enrolled at upper-secondary schools in election years 1998-2010 have been divided into quartiles depending on their family SES, and a model has been estimated for each quartile. For more information about the variables, see Table A5. 
Table A7: Turnout in European Parliamentary election 2009 among students enrolled in different election years 1998-2006. OLS regressions

\begin{tabular}{|c|c|c|c|}
\hline & 1998 & 2002 & 2006 \\
\hline Mock election & $\begin{array}{l}-0.00448 \\
(0.00344)\end{array}$ & $\begin{array}{c}0.00161 \\
(0.00282)\end{array}$ & $\begin{array}{c}0.00206 \\
(0.00305)\end{array}$ \\
\hline School: Parents voted (general) & $\begin{array}{c}0.0423 \\
(0.0509)\end{array}$ & $\begin{array}{l}-0.109^{*} \\
(0.0647)\end{array}$ & $\begin{array}{c}-0.443^{* * *} \\
(0.0652)\end{array}$ \\
\hline School: Parents voted (EP) & $\begin{array}{l}0.326^{* * *} \\
(0.0283)\end{array}$ & $\begin{array}{l}0.421^{* * *} \\
(0.0347)\end{array}$ & $\begin{array}{l}0.402^{* * *} \\
(0.0328)\end{array}$ \\
\hline School: GPA (std.) & $\begin{array}{c}-0.0521^{* * *} \\
(0.00550)\end{array}$ & $\begin{array}{c}-0.0482^{* * *} \\
(0.00548)\end{array}$ & $\begin{array}{c}-0.0402^{* * *} \\
(0.00478)\end{array}$ \\
\hline Female & $\begin{array}{c}-0.0183^{* * *} \\
(0.00235)\end{array}$ & $\begin{array}{c}-0.00742^{* * *} \\
(0.00230)\end{array}$ & $\begin{array}{c}-0.0337^{* * *} \\
(0.00209)\end{array}$ \\
\hline Parents voted (general) & $\begin{array}{l}0.0559^{* * *} \\
(0.00434)\end{array}$ & $\begin{array}{l}0.0360^{* * *} \\
(0.00338)\end{array}$ & $\begin{array}{c}0.00770^{* *} \\
(0.00306)\end{array}$ \\
\hline Parents voted (EP) & $\begin{array}{c}0.232^{* * *} \\
(0.00270)\end{array}$ & $\begin{array}{c}0.285^{* * *} \\
(0.00276)\end{array}$ & $\begin{array}{c}0.484^{* * *} \\
(0.00254)\end{array}$ \\
\hline GPA (std.) & $\begin{array}{l}0.0641^{* * *} \\
(0.00198)\end{array}$ & $\begin{array}{l}0.0627^{* * *} \\
(0.00157)\end{array}$ & $\begin{array}{l}0.0428^{* * *} \\
(0.00135)\end{array}$ \\
\hline Birth year fixed effects & $\checkmark$ & $\checkmark$ & $\checkmark$ \\
\hline School programme fixed effects & $\checkmark$ & $\checkmark$ & $\checkmark$ \\
\hline Immigration background fixed effects & $\checkmark$ & $\checkmark$ & $\checkmark$ \\
\hline$N$ & 208,283 & 244,443 & 289,346 \\
\hline
\end{tabular}


Table A8: Turnout in parliamentary election 2010 among students enrolled in election years 1998-2010. Logit regressions

\begin{tabular}{|c|c|c|c|c|}
\hline & 1 & 2 & 3 & 4 \\
\hline Mock election & $\begin{array}{c}0.0673^{\text {*** }} \\
(0.0215)\end{array}$ & $\begin{array}{c}0.0111 \\
(0.0109)\end{array}$ & $\begin{array}{c}0.0175 \\
(0.0118)\end{array}$ & $\begin{array}{c}0.00202 \\
(0.00148)\end{array}$ \\
\hline School: Parents voted (general) & & $\begin{array}{c}3.141^{* * *} \\
(0.210)\end{array}$ & & $\begin{array}{c}0.0930^{* * *} \\
(0.0313)\end{array}$ \\
\hline School: Parents voted (EP) & & $\begin{array}{c}1.826^{* * *} \\
(0.125)\end{array}$ & & $\begin{array}{l}0.168^{* * *} \\
(0.0162)\end{array}$ \\
\hline School: Family SES & & $\begin{array}{c}0.0522 \\
(0.0396)\end{array}$ & & $\begin{array}{c}-0.0107^{* *} \\
(0.00479)\end{array}$ \\
\hline School: GPA (std.) & & $\begin{array}{c}0.0941^{* * *} \\
(0.0213)\end{array}$ & & $\begin{array}{c}-0.0261^{* * *} \\
(0.00273)\end{array}$ \\
\hline Parents voted (general) & & & $\begin{array}{l}1.316^{* * *} \\
(0.0137)\end{array}$ & $\begin{array}{c}0.260^{* * *} \\
(0.00305)\end{array}$ \\
\hline Parents voted (EP) & & & $\begin{array}{c}0.628^{* * *} \\
(0.00796)\end{array}$ & $\begin{array}{l}0.0695^{* * *} \\
(0.00106)\end{array}$ \\
\hline Female & & & $\begin{array}{c}0.122^{* * *} \\
(0.00899)\end{array}$ & $\begin{array}{l}0.0122^{* * *} \\
(0.00107)\end{array}$ \\
\hline Family SES & & & $\begin{array}{c}0.0695^{* * *} \\
(0.00597)\end{array}$ & $\begin{array}{c}0.00389^{* * *} \\
(0.000645)\end{array}$ \\
\hline GPA (std.) & & & $\begin{array}{c}0.233^{* * *} \\
(0.00623)\end{array}$ & $\begin{array}{c}0.0320^{* * *} \\
(0.000778)\end{array}$ \\
\hline Birth year fixed effects & $\checkmark$ & $\checkmark$ & $\checkmark$ & $\checkmark$ \\
\hline School programme fixed effects & & & $\checkmark$ & $\checkmark$ \\
\hline Immigration background fixed effects & & & $\checkmark$ & $\checkmark$ \\
\hline$N$ & 820,059 & 820,059 & 820,059 & 820,059 \\
\hline
\end{tabular}

Notes: Standard errors in parentheses. The models are estimated using logit models on pooled data of students enrolled at upper-secondary schools in 1998, 2002, 2006, and 2010. Variables with 'School' prefix refer to averages at school level. Variables regarding turnout refer to voting in the 2010 parliamentary election (general) and the 2009 European Parliament election (EP). Family SES is an average of parental earnings, parental education, and parental occupational status, where all items initially have been standardised to have a mean of 0 and a standard deviation of 1 . GPA refers to average grade in class 9 , standardised for each year. School programme refers to the 18 national and 5 introductory programmes available at upper-secondary schools. Immigration background is classified into four categories: the first three refer to people born in Sweden with both, only one, or none of their parents born in Sweden, and the fourth category contain foreign-born persons. 
Table A9: Turnout in parliamentary election 2010 among students enrolled in election years 1998-2010, by family SES quartile. Logit regressions

\begin{tabular}{lcccc}
\hline \hline & Q1 & Q2 & Q3 & Q4 \\
\hline Mock election & 0.0182 & 0.00962 & 0.0188 & 0.0299 \\
& $(0.0152)$ & $(0.0160)$ & $(0.0180)$ & $(0.0200)$ \\
School: Parents voted (general) & $0.769^{* * *}$ & $0.754^{* *}$ & 0.253 & 0.135 \\
& $(0.290)$ & $(0.350)$ & $(0.399)$ & $(0.480)$ \\
School: Parents voted (EP) & $0.907^{* * *}$ & $1.364^{* * *}$ & $1.543^{* * *}$ & $2.128^{* * *}$ \\
& $(0.161)$ & $(0.180)$ & $(0.190)$ & $(0.260)$ \\
School: GPA (std.) & $-0.212^{* * *}$ & $-0.223^{* * *}$ & $-0.246^{* * *}$ & $-0.156^{* * *}$ \\
& $(0.0314)$ & $(0.0318)$ & $(0.0280)$ & $(0.0368)$ \\
Female & $0.146^{* * *}$ & $0.145^{* * *}$ & $0.0720^{* * *}$ & $0.0965^{* * *}$ \\
& $(0.0145)$ & $(0.0159)$ & $(0.0156)$ & $(0.0169)$ \\
Parents voted (general) & $1.253^{* * *}$ & $1.405^{* * *}$ & $1.379^{* * *}$ & $1.320^{* * *}$ \\
& $(0.0184)$ & $(0.0222)$ & $(0.0278)$ & $(0.0392)$ \\
Parents voted (EP) & & & \\
& $0.533^{* * *}$ & $0.600^{* * *}$ & $0.632^{* * *}$ & $0.670^{* * *}$ \\
GPA (std.) & $(0.0152)$ & $(0.0152)$ & $(0.0148)$ & $(0.0182)$ \\
& & & \\
Birth year fixed effects & $0.217^{* * *}$ & $0.265^{* * *}$ & $0.270^{* * *}$ & $0.243^{* * *}$ \\
School programme fixed effects & $(0.00820)$ & $(0.00811)$ & $(0.00906)$ & $(0.0112)$ \\
Immigration background fixed effects & $\checkmark$ & $\checkmark$ & $\checkmark$ & $\checkmark$ \\
\hline$N$ & $\checkmark$ & $\checkmark$ & $\checkmark$ & $\checkmark$ \\
\hline \hline & $\checkmark$ & $\checkmark$ & $\checkmark$ & $\checkmark$ \\
\hline$* 0.10,^{* *} p<0.05,^{* * *} p<0.01$ & & & & \\
\hline
\end{tabular}

Notes: Results from logit regressions. Standard errors in parentheses. Students enrolled at upper-secondary schools in election years 1998-2010 have been divided into quartiles depending on their family SES, and a model has been estimated for each quartile. Family SES is an average of parental earnings, parental education, and parental occupational status, where all items initially have been standardised to have a mean of 0 and a standard deviation of 1 . For information about the other variables, see Table A5. 
Table A10: Turnout in parliamentary election 2010 among students enrolled in different election years 1998-2010. Logit regressions

\begin{tabular}{|c|c|c|c|c|}
\hline & 1998 & 2002 & 2006 & 2010 \\
\hline Mock election & $\begin{array}{l}0.00672 \\
(0.0256)\end{array}$ & $\begin{array}{r}0.000107 \\
(0.0178)\end{array}$ & $\begin{array}{c}0.0353^{* *} \\
(0.0180)\end{array}$ & $\begin{array}{c}0.0322 \\
(0.0399)\end{array}$ \\
\hline School: Parents voted (general) & $\begin{array}{c}1.243^{* * *} \\
(0.309)\end{array}$ & $\begin{array}{c}1.198^{* * *} \\
(0.381)\end{array}$ & $\begin{array}{c}-0.880^{* *} \\
(0.388)\end{array}$ & $\begin{array}{l}-0.809 \\
(0.731)\end{array}$ \\
\hline School: Parents voted (EP) & $\begin{array}{c}1.204^{* * *} \\
(0.168)\end{array}$ & $\begin{array}{c}1.318^{* * *} \\
(0.198)\end{array}$ & $\begin{array}{c}1.448^{* * *} \\
(0.190)\end{array}$ & $\begin{array}{c}1.783^{* * *} \\
(0.356)\end{array}$ \\
\hline School: GPA (std.) & $\begin{array}{c}-0.203^{* * *} \\
(0.0295)\end{array}$ & $\begin{array}{c}-0.244^{* * *} \\
(0.0304)\end{array}$ & $\begin{array}{c}-0.220^{* * *} \\
(0.0323)\end{array}$ & $\begin{array}{c}-0.0999 \\
(0.0663)\end{array}$ \\
\hline Female & $\begin{array}{c}0.0929^{* * *} \\
(0.0161)\end{array}$ & $\begin{array}{l}0.164^{* * *} \\
(0.0143)\end{array}$ & $\begin{array}{c}0.0986^{* * *} \\
(0.0126)\end{array}$ & $\begin{array}{l}0.133^{* * *} \\
(0.0329)\end{array}$ \\
\hline Parents voted (general) & $\begin{array}{l}1.069^{* * *} \\
(0.0240)\end{array}$ & $\begin{array}{l}1.117^{* * *} \\
(0.0211)\end{array}$ & $\begin{array}{l}1.410^{* * *} \\
(0.0205)\end{array}$ & $\begin{array}{l}2.364^{* * *} \\
(0.0443)\end{array}$ \\
\hline Parents voted (EP) & $\begin{array}{l}0.510^{* * *} \\
(0.0169)\end{array}$ & $\begin{array}{l}0.577^{* * *} \\
(0.0142)\end{array}$ & $\begin{array}{l}0.681^{* * *} \\
(0.0131)\end{array}$ & $\begin{array}{c}0.762^{* * *} \\
(0.0348)\end{array}$ \\
\hline GPA (std.) & $\begin{array}{c}0.229^{* * *} \\
(0.00927)\end{array}$ & $\begin{array}{c}0.267^{* * *} \\
(0.00844)\end{array}$ & $\begin{array}{c}0.235^{* * *} \\
(0.00770)\end{array}$ & $\begin{array}{l}0.268^{* * *} \\
(0.0146)\end{array}$ \\
\hline Birth year fixed effects & $\checkmark$ & $\checkmark$ & $\checkmark$ & $\checkmark$ \\
\hline School programme fixed effects & $\checkmark$ & $\checkmark$ & $\checkmark$ & $\checkmark$ \\
\hline Immigration background fixed effects & $\checkmark$ & $\checkmark$ & $\checkmark$ & $\checkmark$ \\
\hline$N$ & 208,807 & 245,471 & 290,264 & 75,541 \\
\hline $\begin{array}{l}{ }^{*} p<0.10,{ }^{* *} p<0.05,{ }^{* * *} p<0.01 \\
\text { Notes: Results from logit regressions. } \\
\text { model has been estimated for studer } \\
1998,2002,2006 \text {, and } 2010 \text {. For infor }\end{array}$ & indard e & P I & eses. A & $\begin{array}{l}\text { arate } \\
\text { ls in } \\
\text { A5 }\end{array}$ \\
\hline
\end{tabular}


Table A11: Turnout in parliamentary election 2010 among students enrolled in election years 1998-2010, by quartiles based on average school GPA. OLS regressions

\begin{tabular}{lcccc}
\hline \hline & Q1 & Q2 & Q3 & Q4 \\
\hline Mock election & 0.000312 & 0.00483 & -0.000168 & -0.000848 \\
& $(0.00303)$ & $(0.00302)$ & $(0.00290)$ & $(0.00234)$ \\
School: Parents voted (general) & 0.00189 & $0.235^{* * *}$ & 0.128 & -0.0431 \\
& $(0.0486)$ & $(0.0825)$ & $(0.0827)$ & $(0.0626)$ \\
School: Parents voted (EP) & $0.184^{* * *}$ & $0.0821^{* *}$ & $0.150^{* * *}$ & $0.242^{* * *}$ \\
& $(0.0305)$ & $(0.0406)$ & $(0.0303)$ & $(0.0275)$ \\
Female & $0.0211^{* * *}$ & $0.0135^{* * *}$ & $0.0126^{* * *}$ & $0.00478^{* * *}$ \\
& $(0.00270)$ & $(0.00219)$ & $(0.00213)$ & $(0.00133)$ \\
Parents voted (general) & $0.285^{* * *}$ & $0.262^{* * *}$ & $0.248^{* * *}$ & $0.228^{* * *}$ \\
& $(0.00501)$ & $(0.00662)$ & $(0.00549)$ & $(0.00660)$ \\
Parents voted (EP) & $0.0809^{* * *}$ & $0.0728^{* * *}$ & $0.0669^{* * *}$ & $0.0577^{* * *}$ \\
& $(0.00206)$ & $(0.00215)$ & $(0.00202)$ & $(0.00187)$ \\
GPA (std.) & & & & \\
Birth year fixed effects & $0.0304^{* * *}$ & $0.0357^{* * *}$ & $0.0333^{* * *}$ & $0.0226^{* * *}$ \\
School programme fixed effects & $(0.00162)$ & $(0.00155)$ & $(0.00152)$ & $(0.00119)$ \\
Immigration background fixed effects & $\checkmark$ & $\checkmark$ & $\checkmark$ & $\checkmark$ \\
\hline$N$ & 206,699 & 203,311 & 200,752 & 209,321 \\
\hline \hline
\end{tabular}

${ }^{*} p<0.10,{ }^{* *} p<0.05,{ }^{* * *} p<0.01$

Notes: Standard errors in parentheses. Students enrolled at upper-secondary schools in election years 1998-2010 have been divided into quartiles depending on the average GPA of the students in their school, and a model has been estimated for each quartile. GPA refers to average grade in class 9, standardised for each year. For information about the other variables, see Table A5. 
Table A12: Turnout in parliamentary election 2010 among students enrolled in election years 1998-2010, by quartiles based on average family SES in school. OLS regressions

\begin{tabular}{|c|c|c|c|c|}
\hline & Q1 & Q2 & Q3 & Q4 \\
\hline Mock election & $\begin{array}{c}0.00469 \\
(0.00289)\end{array}$ & $\begin{array}{c}0.00291 \\
(0.00308)\end{array}$ & $\begin{array}{l}-0.00124 \\
(0.00267)\end{array}$ & $\begin{array}{c}0.00107 \\
(0.00247)\end{array}$ \\
\hline School: Parents voted (general) & $\begin{array}{l}0.0992^{* *} \\
(0.0504)\end{array}$ & $\begin{array}{c}0.159^{*} \\
(0.0913)\end{array}$ & $\begin{array}{c}0.0601 \\
(0.0916)\end{array}$ & $\begin{array}{l}-0.0415 \\
(0.0629)\end{array}$ \\
\hline School: Parents voted (EP) & $\begin{array}{l}0.137^{* * *} \\
(0.0292)\end{array}$ & $\begin{array}{l}0.112^{* * *} \\
(0.0429)\end{array}$ & $\begin{array}{l}0.177^{* * *} \\
(0.0309)\end{array}$ & $\begin{array}{l}0.251^{* * *} \\
(0.0265)\end{array}$ \\
\hline School: GPA (std.) & $\begin{array}{c}-0.0305^{* * *} \\
(0.00614)\end{array}$ & $\begin{array}{c}-0.0270^{* * *} \\
(0.00876)\end{array}$ & $\begin{array}{c}-0.0271^{* * *} \\
(0.00614)\end{array}$ & $\begin{array}{c}-0.0178^{* * *} \\
(0.00293)\end{array}$ \\
\hline Female & $\begin{array}{l}0.0118^{* * *} \\
(0.00246)\end{array}$ & $\begin{array}{l}0.0180^{* * *} \\
(0.00249)\end{array}$ & $\begin{array}{l}0.0124^{* * *} \\
(0.00202)\end{array}$ & $\begin{array}{c}0.00723^{* * *} \\
(0.00155)\end{array}$ \\
\hline Parents voted (general) & $\begin{array}{c}0.274^{* * *} \\
(0.00534)\end{array}$ & $\begin{array}{c}0.264^{* * *} \\
(0.00599)\end{array}$ & $\begin{array}{c}0.258^{* * *} \\
(0.00606)\end{array}$ & $\begin{array}{c}0.231^{* * *} \\
(0.00592)\end{array}$ \\
\hline Parents voted (EP) & $\begin{array}{l}0.0740^{* * *} \\
(0.00216)\end{array}$ & $\begin{array}{l}0.0727^{* * *} \\
(0.00217)\end{array}$ & $\begin{array}{l}0.0706^{* * *} \\
(0.00193)\end{array}$ & $\begin{array}{l}0.0601^{* * *} \\
(0.00195)\end{array}$ \\
\hline GPA (std.) & $\begin{array}{l}0.0357^{* * *} \\
(0.00148)\end{array}$ & $\begin{array}{c}0.0357^{* * *} \\
(0.00142)\end{array}$ & $\begin{array}{l}0.0357^{* * *} \\
(0.00153)\end{array}$ & $\begin{array}{l}0.0214^{* * *} \\
(0.00122)\end{array}$ \\
\hline Birth year fixed effects & $\checkmark$ & $\checkmark$ & $\checkmark$ & $\checkmark$ \\
\hline School programme fixed effects & $\checkmark$ & $\checkmark$ & $\checkmark$ & $\checkmark$ \\
\hline Immigration background fixed effects & $\checkmark$ & $\checkmark$ & $\checkmark$ & $\checkmark$ \\
\hline$N$ & 204,830 & 202,084 & 206,465 & 206,704 \\
\hline
\end{tabular}

Notes: Standard errors in parentheses. Students enrolled at upper-secondary schools in election years 1998-2010 have been divided into quartiles depending on the average family SES among the students in their school, and a model has been estimated for each quartile. Family SES is an average of parental earnings, parental education, and parental occupational status, where all items initially have been standardised to have a mean of 0 and a standard deviation of 1 . For information about the other variables, see Table A5 


\section{References}

Bihagen, E. (2007). Nya möjligheter för stratifieringsforskning i Sverige. Sociologisk forskning 44(1), 52-67.

Ganzeboom, H. B., P. M. D. Graaf, and D. J. Treiman (1992). A standard international socio-economic index of occupational status. Social Science Research 21 (1), 1-56.

Meraviglia, C., H. B. Ganzeboom, and D. D. Luca (2016). A new international measure of social stratification. Contemporary Social Science 11(2), $125-153$.

Prandy, K. and F. L. Jones (2001). An international comparative analysis of marriage patterns and social stratification. International Journal of Sociology and Social Policy 21(4/5/6), 165-183.

Treiman, D. J. (1977). Occupational Prestige in Comparative Perspective. New York: Academic Press. 